\title{
Volcanic unrest scenarios and impact assessment at Campi Flegrei caldera, Southern Italy
}

\author{
Danielle Charlton ${ }^{1,2^{*}}$ (D), Christopher Kilburn ${ }^{2,3}$ and Stephen Edwards ${ }^{2}$
}

\begin{abstract}
At Campi Flegrei caldera, volcanic unrest hazards during 1982-1984 caused significant building damage and led to the evacuation of over 40,000 residents in the central town of Pozzuoli. Past hazard assessments in this region have focused on eruption hazards rather than on hazards from volcanic unrest. In this study, we developed a hypothetical unrest hazard scenario applied to three locations within Campi Flegrei caldera: Pozzuoli, Agnano and Baia. We also collated GIS exposure datasets and used vulnerability models of building and road damage to carry out an impact assessment for future volcanic unrest at these three test locations. The resulting impact maps provide useful insight into the effects future unrest could have on businesses, buildings and livelihoods within Campi Flegrei.

The impact maps show that, depending on the location of unrest, evacuations associated with future unrest may involve displacement of large numbers of residents, and significant damage to buildings and infrastructure. The Agnano scenario is associated with the greatest impact and involves the potential evacuation of 136,000 people and damage to about 2400 buildings, with up to $200 \mathrm{~km}$ of roads and $17 \mathrm{~km}$ of high-voltage electricity network also exposed. Agnano also lies between Naples and the rest of Campi Flegrei, so that damage to infrastructure may trigger a cascade of obstacles to managing evacuations and repairs during an emergency. The results highlight how a simple impact assessment can be used to explore the possible effects of future unrest hazard, and the importance of considering scenarios in which renewed ground uplift is not necessarily focused beneath Pozzuoli.
\end{abstract}

Keywords: Scenario, Campi Flegrei, Impact assessment, Volcanic unrest, GIS

\section{Introduction}

About 20 large calderas show episodes of volcanic unrest each year (Newhall and Dzurisin 1988; Acocella et al. 2015). The range of hazards they produce is similar to that from unrest at volcanoes in general. However, whereas general volcanic unrest commonly occurs for months or less, unrest at large calderas

\footnotetext{
* Correspondence: danielle.charlton@auckland.ac.nz

'School of Environment, University of Auckland, 23 Symonds Street, Auckland 1142, New Zealand

${ }^{2}$ UCL Hazard Centre, Department of Earth Sciences, University College London, Gower Street, London WC1E 6BT, UK

Full list of author information is available at the end of the article
}

can continue for years or more (Phillipson et al. 2013; Potter et al. 2015; Acocella et al. 2015). Even without an eruption, therefore, caldera unrest can significantly disrupt the livelihoods of local residents and regional economies (Barberi et al. 1984; Johnston et al. 2002; Potter et al. 2015; Longo 2019).

The hazards from unrest include volcano-tectonic (VT) seismicity, ground uplift, hydrothermal explosions, the opening of faults and fractures, increased degassing and landslides (Newhall and Dzurisin 1988). They may cause severe physical damage to buildings, transportation networks and critical infrastructures, 
such as electricity, water and telecommunications networks (Barberi et al. 1984; Mader et al. 1987; Johnston et al. 2002). Such damage, in turn, may induce significant economic loss through business interruption (Hughes and Healy 2014), decreases in property values and increases in insurance premiums (Kuester and Forsyth 1985; Benson 2006). In addition, tourism and the revenue it brings can also be affected. Tourist income dropped significantly at Long Valley Caldera in the US during 1978-1983 unrest period (Blong 1984) and at Taupō caldera in New Zealand during 1964 (Johnston et al. 2002). When extended evacuations are necessary, the impacts of unrest are exacerbated by restrictions on effecting repairs (Deligne et al. 2017) and by uncertainty and fear amongst local communities (Longo 2019), often fuelled by ambiguous and sensational media reports (Blong 1984; Lowenstein 1988; Johnston et al. 2002; Benson 2006). The latter was experienced by communities at Rabaul caldera in Papua New Guinea, where unrest between 1983 and 1985 and subsequent media attention caused losses estimated at over US\$22.2 million (Lowenstein 1988). This was primarily due to a fall in property values, increases in seismic risk levies on insurance premiums and 10,000 people being evacuated (Kuester and Forsyth 1985; Benson 2006).

Scenarios are stories about how the future events might occur, aimed to stimulate conversations between a diverse range of stakeholders. Based on clear assumptions about key deterministic relationships, scenarios describe plausible futures that are intended to be explored, discussed and debated. Strong et al. (2020) suggest they are important for supporting creative thinking about possible futures, rather than attempting to accurately predict individual outcomes. Realistic disaster scenarios are commonly used in the insurance industry to assess losses from specific hazardous events (Mitchell-Wallace et al. 2017). Scenarios and impact assessments are also used in the Disaster Risk Reduction (DRR) setting by emergency managers, Non-Governmental Organisations and the scientific community to explore the range of possible impacts from volcanic eruptions (e.g. Hayes et al. 2020; Kaye et al. 2009; Zuccaro et al. 2008). Whilst these examples primarily consider hazards related to eruptions, very few consider the effects of volcanic unrest. Blake et al. (2017) evaluated the impacts of a scenario of unrest and eruption in the Auckland Volcanic Field, New Zealand, on transportation networks in Auckland for use by local decision makers. A companion study by Deligne et al. (2017) demonstrated how the same scenario can impact the electricity network in the city. They discovered that volcanic unrest could lead to more disruption to transportation and greater numbers of evacuees compared to hazards from an eruption itself, owing to scientific uncertainty in evaluating possible outcomes and the longer length of the unrest. Clearly, the impacts of unrest hazards are not to be underestimated, especially in highly populated volcanic settings where disruption could continue for long periods. In this context, impact can be simply defined as the outcome of the interaction of a hazard and an asset (Panza et al. 2011). Human impact measures the outcome of the interaction between a hazard of a given intensity and the personal, community and societal factors implemented to cope, adapt, and recover from hazard effects (Paton et al. 2013).

In Campi Flegrei, a large caldera in Southern Italy, hazards from volcanic unrest and associated evacuations during the 1970s and 1980s caused significant disruption to livelihoods mainly within the largest town within the caldera, Pozzuoli (Barberi et al. 1984; Longo 2019). A risk perception survey carried in the region found that survey respondents considered unrest hazards more serious threats compared to the threat from eruptive phenomena (Ricci et al. 2013). Despite this, there has been limited research investigating what could happen if similar unrest episodes at Campi Flegrei occur now or in the future. In order to understand more about future unrest at Campi Flegrei, we present a new set of impact maps, exploring the potential effect of hazards from noneruptive unrest on the population and built assets in Campi Flegrei. Our aim was to develop a single realistic unrest scenario that incorporated likely unrest hazards and then apply this in three different areas around the caldera developing individual impact maps. To do this, we created a new GIS database of the spatial distribution of potentially exposed assets across the caldera and then assessed the spatial interactions between a hypothetical unrest hazard scenario and these assets and where possible, asset vulnerability, in the three selected areas within Campi Flegrei.

\section{Volcanic unrest and the volcanic hazard management context at Campi Flegrei caldera}

\section{Twentieth century unrest at Campi Flegrei}

The Campi Flegrei caldera, provides a classic example of how unrest can have a large impact on local communities. About $12 \mathrm{~km}$ across, its eastern margin overlaps with the suburbs of Naples and it has erupted at least 60 times since the Neapolitan Yellow Tuff caldera forming eruption 15,600 years ago (Fig. 1). Since 1950, it has been in intermittent unrest in the form of caldera-wide uplift, which has 


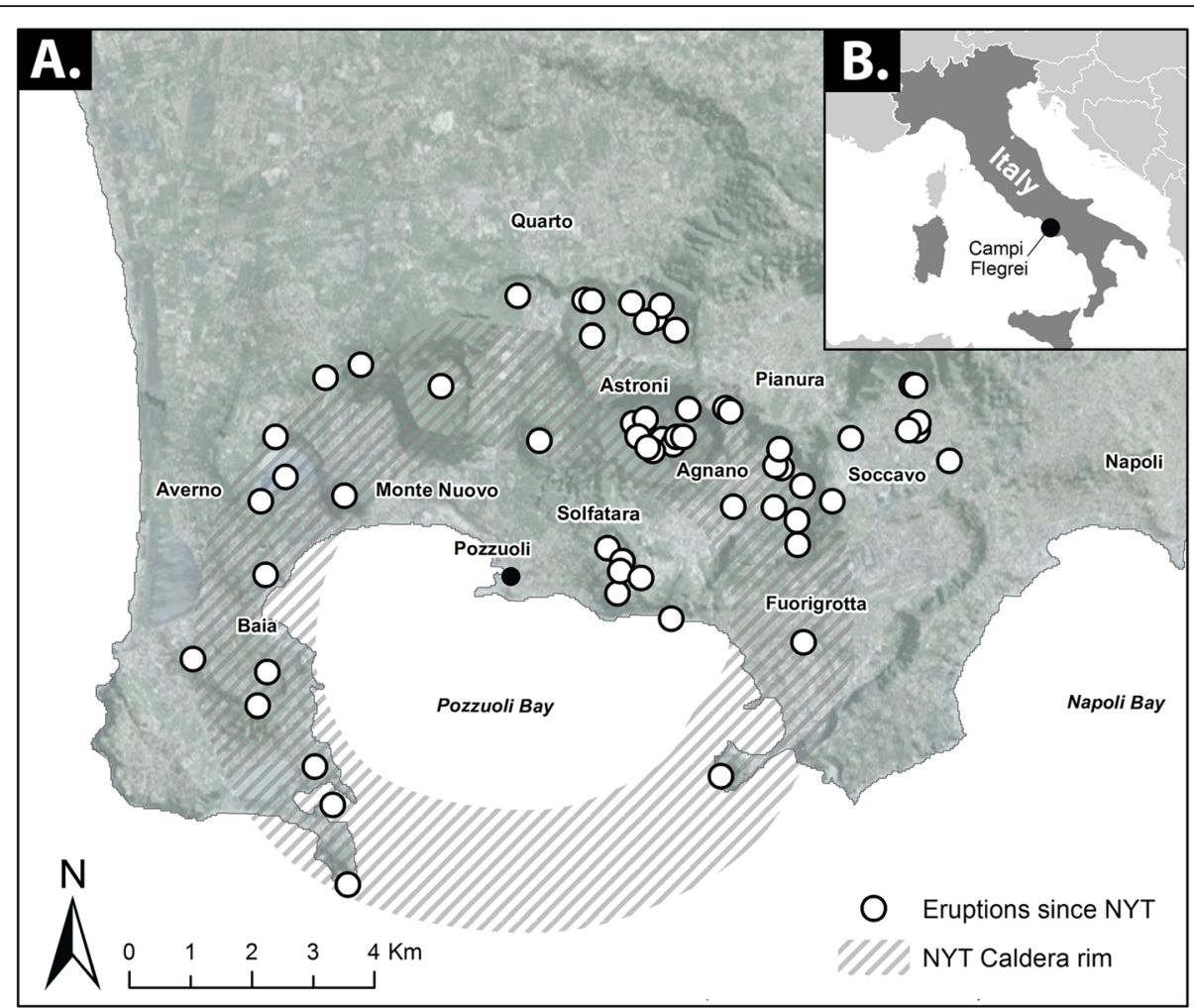

Fig. 1 a. Location map of Campi Flegrei caldera. The rim of the caldera associated with the last caldera collapse 15.6 ka BP (Neapolitan Yellow Tuff eruption; Barberi et al. 1991) is represented by the hash lines. The location of the 61 past vent locations are shown by the white circles (Smith et al. 2011) and the town of Pozzuoli by a black circle. b. The location of Campi Flegrei within Italy. Background data obtained from google maps

been largest in the coastal town of Pozzuoli, near the centre of the caldera, and VT seismicity at depths of $4 \mathrm{~km}$ or less. Major uplifts occurred in 1950-51, 1969-72 and 1982-84 (Del Gaudio et al. 2010). These cumulatively raised Pozzuoli by more than $4 \mathrm{~m}$ and, in the two more recent cases, triggered mass evacuations from Pozzuoli of some 40, 000 people (Barberi et al. 1984). Following a slow subsidence at Pozzuoli by $0.5 \mathrm{~m}$ between 1984 and 2000, a slow uplift had raised the town to its 1984 level by 2016 (Kilburn et al. 2017; Troise et al. 2019). In 2016, the caldera was home to 350,000 people, an increase of $16 \%$ since the 1982-84 unrest episode (ISTAT 2016).

These uplifts are the first to have occurred in more than four centuries and suggest that the caldera is responding to a new disturbance in the magmatic system. Debate continues about how much of the uplift can be attributed to the intrusion of magma at depths of about $3 \mathrm{~km}$ (Kilburn et al. 2017), the accumulation of magmatic gases from depth (Bodnar et al. 2007; Lima et al. 2009), or disturbances in the flow of shallow hydrothermal fluids (Troiano et al. 2011). In all cases, they appear to belong to a single, evolving sequence of long-term disturbance that continues today (Kilburn et al. 2017).

\section{Volcanic unrest of 1982-84}

The most disruptive episode occurred during 198284 , with the largest earthquake (magnitude 4.2) and amount of uplift occurring (1.8 m: Berrino et al. 1984; Pingue et al. 2011). Just after the magnitude 4.2 earthquake on October 4th, 1983, commerce in the main town of Pozzuoli came to a standstill and schools and some public offices closed. The harbour could not be used and life within the town was disrupted with on-going seismicity that could be felt by residents. In the days following, nearly 40,000 residents were evacuated from the central town of Pozzuoli because the seismic hazard was judged to be too high to ensure the safety of most buildings (Barberi et al. 1984). On November 7th 1983, the central government approved a plan to construct 5000 apartments in the area of Monte Ruscello, $5 \mathrm{~km}$ northwest of Pozzuoli, to be used by people whose homes had been severely damaged. The evacuation and 
disruption caused significant psychological distress amongst residents and workers in Pozzuoli and Monte Ruscello (Maj et al. 1989; Bland et al. 2005). Seismicity and ground deformation began to subside in late November 1983, and the emergency had cleared by 1984 . In total, the earthquakes and associated ground movement caused major damage to at least 70 buildings and disrupted the livelihoods of numerous businesses in Pozzuoli (Barberi et al. 1984; Branno et al. 1984).

\section{Volcanic hazard and risk management context}

The Italian National Department of Civil Protection (DCP) is the main agency responsible for the communication of volcanic hazard and risk at Campi Flegrei. As of 2020, one official hazard map has been published; an emergency plan is yet to be operational. The hazard map encompasses the whole caldera and is based on at least 15 assessments of eruptive hazard (DCP 2014). However, the awareness and understanding of volcanic hazard remains low in this region (Davis et al. 2005; Ricci et al. 2013; Avvisati et al. 2019). There has been very little knowledge of any emergency plan in development within the general population (Ricci et al. 2013). This highlights the need for more effective and co-developed communication strategies helping communities prepare for the impacts of volcanic activity. New strategies to improve communications are now being developed at the Comune level (Comune di Napoli 2019).

Within the scientific community, physical science research has focussed on improving understanding of the hazards of an actual eruption (Alberico et al. 2002, 2011; Bevilacqua et al. 2012, 2015, 2017; Mastrolorenzo et al. 2006; Neri et al. 2015; Orsi et al.
2004, 2009; Paris et al. 2019; Selva et al. 2012, 2014, 2018); less attention has been paid to the societal impacts from extended volcanic unrest and evacuation (Zuccaro and Cacace 2010; Alberico et al. 2012). Alberico et al. (2012) modelled a caldera wide evacuation focusing on the availability of and access to the transportation network. Whereas Zuccaro and Cacace (2010) evaluated cumulative building damage and related probabilities of road interruption due to a sequence of seismic events at both Campi Flegrei and Vesuvius. Their analysis, however, did not consider the impact of ground uplift, which has been argued to have caused most of the damage to buildings during the 1969-72 and 1982-84 unrests (Pingue et al. 2011). Both studies suggested the need for further investigation on how hazardous events can cause cascading impacts and disrupt livelihoods.

\section{Methodology}

New unrest impact maps were developed in three stages: 1) establishing unrest hazard scenario parameters and locations; 2) creating a database of exposed assets and where possible asset vulnerability; and 3) combining hazard scenarios, exposure and vulnerability to assess and map potential impact (Fig. 2).

\section{The design of the unrest hazard scenario Location}

Uplift since at least 1969 has been centred on a coastal location about $1 \mathrm{~km}$ east of Pozzuoli (Bianchi et al. 1987; INGV 2016). The amount of uplift has decayed away from the centre in an approximately radial pattern, decreasing to $10 \%$ of the maximum value at a distance of about $5 \mathrm{~km}$ (Figs. 3 and 4). A similar area appears to have been affected by ground

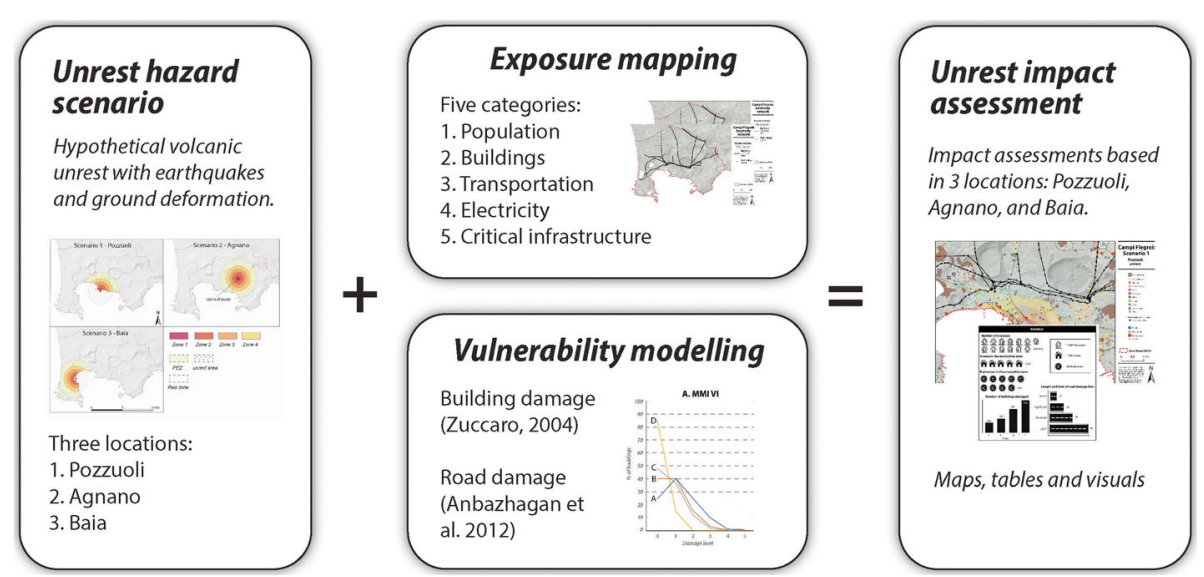

Fig. 2 Methodological approach used in this study, detailing the three stages: 1. defining the unrest hazard scenario; 2. creating an exposure spatial database and related vulnerability modelling for buildings and road damage; and 3. combining all of the elements into three impact assessments for different geographic regions of Campi Flegrei caldera 

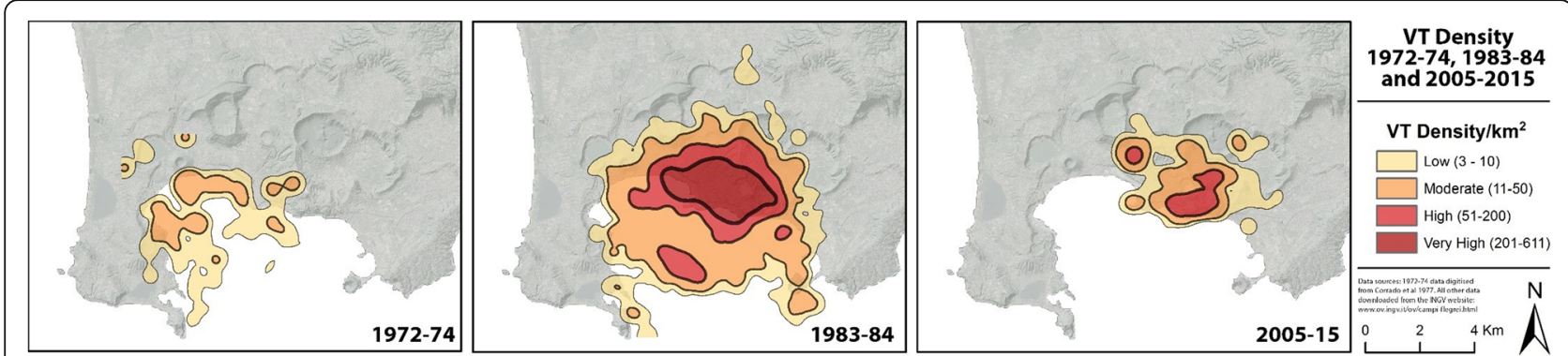

Fig. 3 The density of VT events from Kernel Density analysis. The 1980s unrest episode was centred on Pozzuoli, but the distribution of seismicity from 1970s and 2005 shows a different pattern. During the 1970s unrest, seismicity was focused in the western regions, more towards the town of Baia. More recently the seismicity pattern has shifted marginally towards Solfatara and Agnano to the East of Pozzuoli (INGV 2016)

deformation since Roman times, including the century of net uplift before the caldera's only historic eruption in 1538 (Bellucci et al. 2006; Di Vito et al. 2016). Shortly before the 1538 eruption of Monte Nuovo, the centre of uplift moved to beneath the site of the future vent, about $3 \mathrm{~km}$ west of Pozzuoli. Conventionally, the shift is considered to have occurred within as little as 2 days before eruption (Lyell 1830; Parascandola 1947); however, a recent study has argued that the shift may have begun as much as 2 years beforehand (Di Vito et al. 2016). Scenarios of future unrest must therefore consider a centre of uplift not only near Pozzuoli, but also at locations kilometres distant.
The location of VT seismicity, mostly at depths of 4 $\mathrm{km}$ or less (Corrado et al. 1977; De Natale et al. 1984; INGV 2016), has also changed during successive uplifts (Fig. 3), from near Baia in west-central Campi Flegrei in 1970-71 (Corrado et al. 1977), to Pozzuoli in 1982-84 (De Natale et al. 1984) and to Agnano in east-central Campi Flegrei since 2005 (INGV 2016). It is not known whether the change in location is stochastic or the result of systematic changes in the physical state of the caldera's crust. As a result, Baia, Pozzuoli and Agnano have all been chosen as locations for the unrest hazard scenario (Fig. 5). The same hypothetical unrest hazard scenario was applied to the three locations.

\section{Surface displacement Campi Flegrei unrest: June 1982 - June 1983}

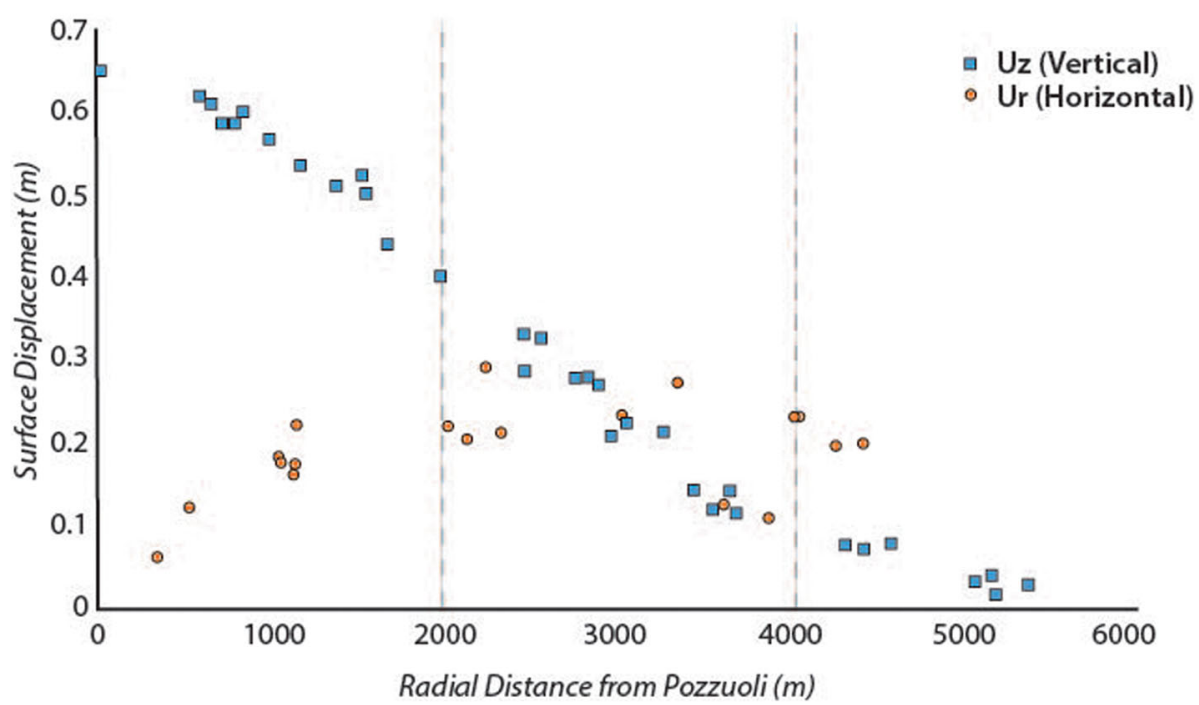

Fig. 4 Horizontal (Ur) and Vertical (Uz) surface displacement pattern from the June 1982-June 1983 unrest episode at Campi Flegrei. Modified from Bianchi et al. (1987) and Woo (2007) 

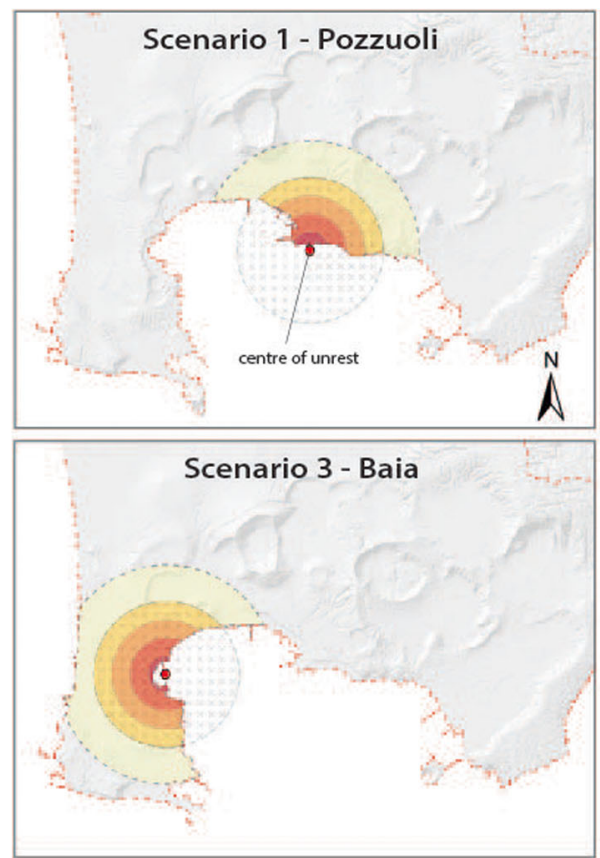

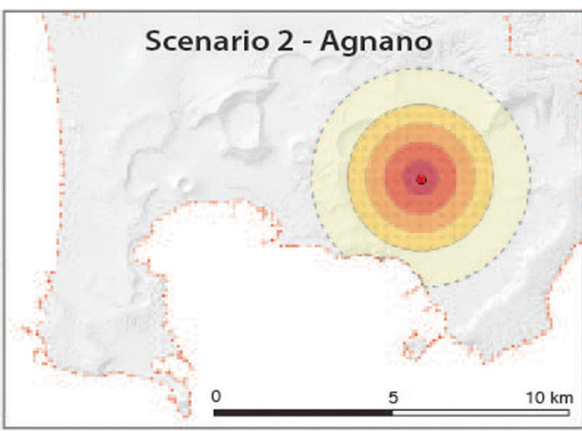

Hypothetical volcanic unrest zones for each scenario location
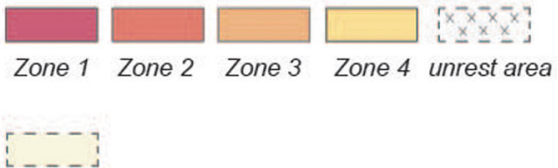

Primary evacuation zone used in scenarios

$[-\cdots]$

Published red zone for Campi Flegrei

(Campania Region Bulletin 29/12/2014)

Fig. 5 Three unrest hazard scenario locations used in this study: (1) Pozzuoli (centred on 14.1239 longitude, 40.819 latitude), (2) Agnano (14.16447 longitude, 40.8375 latitude), and (3) Baia (14.07633 Longitude, 40.81907 latitude). Zones 1 through 4 are used in the exposure assessment and relate to the different distances from the central area of unrest. For the impact assessment, Zones 1 and 2 were grouped and used to represent areas that would experience shaking equal to a seismic intensity of VII on the Modified Mercalli Intensity (MMI) scale and a deformation of greater than $1 \mathrm{~m}$. Zones 3 and 4 were also grouped and relate to seismic intensity MMI VI and ground uplift of less than $1.0 \mathrm{~m}$. The zona rossa, or 'red zone', is the area of evacuation in the event of volcanic unrest at Campi Flegrei determined by the Department of Civil Protection (DCP 2014) and is included for comparison on these maps. This red zone includes the area exposed to pyroclastic flows, and includes the municipalities of Pozzuoli, Bacoli, Monte di Procida and Quarto and some of the municipalities of Giuglianow in Campania, Marano di Napoli and Naples

\section{Hazard intensity}

The greatest physical damage to date from Campi Flegrei's unrest occurred during the 1982-84 crisis and so the seismic and deformation characteristics of this episode have been used to demonstrate the methodology. Most building damage in 1982-84 occurred within $2 \mathrm{~km}$ of the centre of uplift, where total vertical movement exceeded about $60 \%$ of its maximum value of $1.8 \mathrm{~m}$ and the final number-density of VT events exceeded 50 events $\mathrm{km}^{-2}$ (Figs. 3 and 4; Barberi et al. 1984; Berrino et al. 1984; Branno et al. 1984; Bianchi et al. 1987; Pingue et al. 2011). The largest VT event during the crisis (Magnitude 4 on October 4th 1983) produced a seismic intensity (Modified Mercalli Intensity, MMI) of VII within $1 \mathrm{~km}$ of the centre of uplift and of VI across the rest of Campi Flegrei (Branno et al. 1984). The relative contributions to damage from ground uplift, persistent VT swarms and large individual VT earthquakes remains unclear.

Based on the 1982-84 data, the new scenarios were developed to cover a circular area $2 \mathrm{~km}$ in radius around the centre of uplift. The area was divided into four zones by distance from the centre: less than 0.5 $\mathrm{km}, 0.5-1 \mathrm{~km}, 1-1.5 \mathrm{~km}$ and $1.5-2 \mathrm{~km}$ (Fig. 5). These four zones are used to divide and display the exposure results. For the impact assessment, each zone was assigned a level of hazard intensity, decreasing from 1 to 4 . Zones 1 and 2 were combined and represent areas that would experience shaking equal to MMI VII seismicity and an uplift greater than $1 \mathrm{~m}$. Zones 3 and 4 were also grouped and represent the areas affected by MMI VI seismicity and uplift of less than $1.0 \mathrm{~m}$ (Fig. 6). For clarity, the unrest hazard intensity is the same for all three scenarios and the only thing that changes between the different locations is the epicentre of the unrest.

\section{Hypothetical evacuation areas}

The unrest hazard scenario area was enclosed by a hypothetical Primary Evacuation Zone (PEZ), $3 \mathrm{~km}$ in radius. Past evacuations have caused significant distress among residents of Pozzuoli (Longo 2019) and the possible area of evacuation is important aspect to consider alongside the hazard area. The size of the 


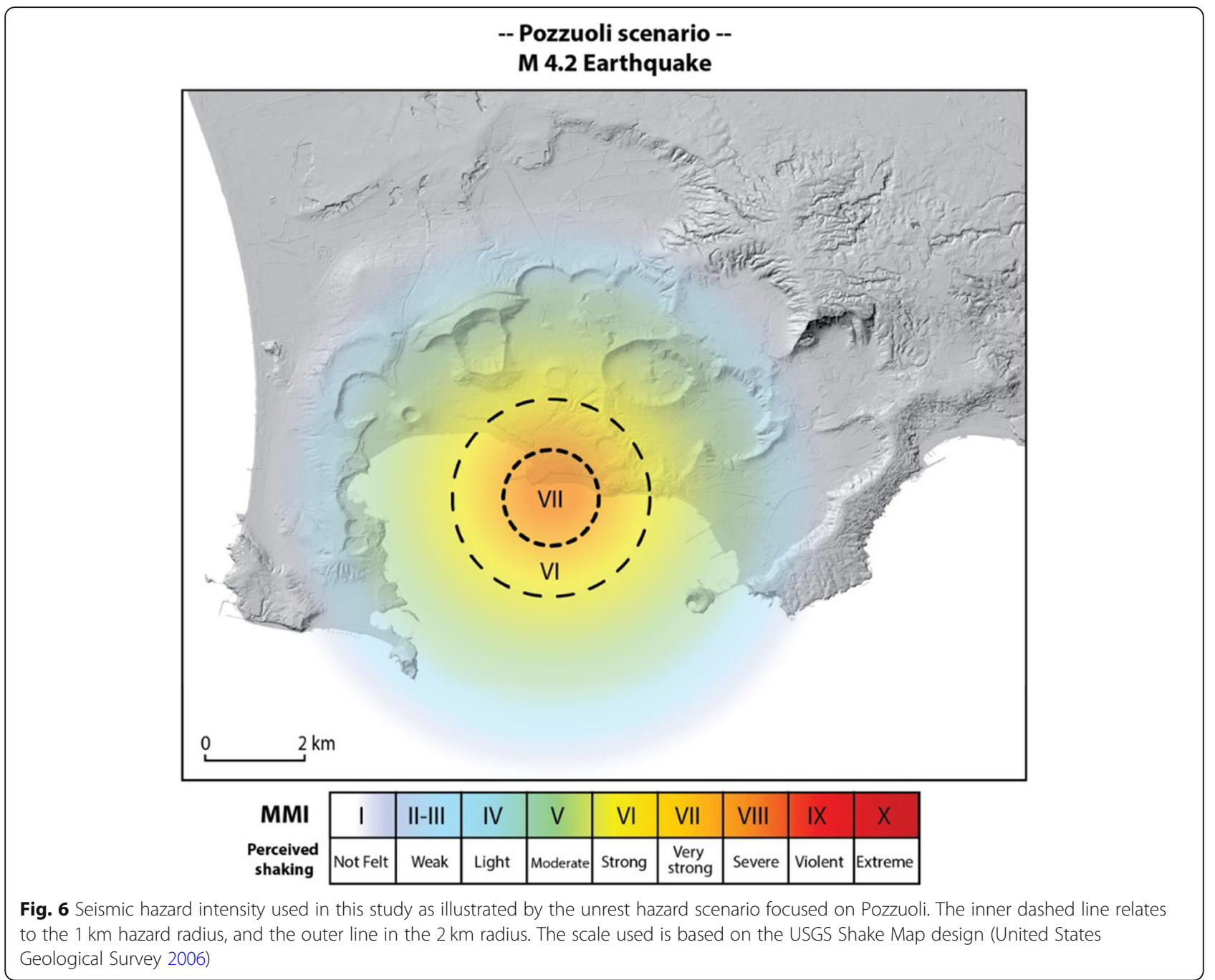

hypothetical PEZ was chosen from approximations of the areas evacuated at Campi Flegrei in 1970 and 1983. The published evacuation zone (zona rossa) for Campi Flegrei is based on the potential for an eruption and it covers the entire on land portion of the caldera floor, i.e. is approximately $100 \mathrm{~km}^{2}$ (DCP 2014). The existing published maps and supporting documents do not include smaller evacuations by area, similar to those ordered in 1970 and 1983. However, a recent multi agency exercise named 'Exe Flegrei 2019' simulated evacuation procedures within the different municipalities of the zona rossa, or red zone, rather than across the whole caldera (Comune di Napoli 2019).

\section{Exposure database}

To assess the exposure of the population and of building and infrastructural assets, a new database was created for Campi Flegrei using ArcGIS (Table 1). The spatial distribution data were sorted to create
ArcGIS shapefiles for five categories: population, buildings, transportation networks, electricity networks and critical facilities. These five categories were chosen as they, together with their associated spatial data, allowed us to begin to explore the potential human and physical impacts of volcanic unrest. In addition, two attributes of buildings were also collected and estimated: age and primary use. A description of how these datasets were collated and their limitations are described below:

\section{Population distribution}

The online 2011 ISTAT database (ISTAT 2016) was used to obtain the total number and distribution of residents in the areas chosen for each unrest hazard scenario location.

\section{Building distribution, use and age}

The distribution of buildings was mapped using data from the 2011 census (ISTAT 2016). A GIS data 
Table 1 Exposure data collected, created and used in this study

\begin{tabular}{|c|c|c|c|}
\hline$\overline{C l a s s}$ & Attributes & Source & Output \\
\hline $\begin{array}{l}\text { Building } \\
\text { Distribution }\end{array}$ & Primary use and age. & $\begin{array}{l}\text { The } 2011 \text { ISTAT census (building age) and the } \\
\text { INGV OpenStreetMap and validated by Google } \\
\text { maps. }\end{array}$ & $\begin{array}{l}\text { ESRI } \\
\text { shapefile }\end{array}$ \\
\hline Population & Density, demographics. & ISTAT 2011 census & $\begin{array}{l}\text { ESRI } \\
\text { shapefile }\end{array}$ \\
\hline Transportation & $\begin{array}{l}\text { Road, rail networks, stations, and bus stops. Access to transportation } \\
\text { networks data constructed by highlighting areas within } 1 \mathrm{~km} \mathrm{(a} \\
\text { distance that can be covered on foot) of motorways, roads and } \\
\text { railway, bus stations, and ferry ports. }\end{array}$ & OpenStreetMap and validated by Google maps. & $\begin{array}{l}\text { ESRI } \\
\text { shapefiles }\end{array}$ \\
\hline Electricity & $\begin{array}{l}\text { High voltage overhead lines and their related substations. Smaller } \\
\text { power and telephone lines were not included because they could not } \\
\text { be identified from aerial imagery. }\end{array}$ & Google Earth imagery & $\begin{array}{l}\text { ESRI } \\
\text { shapefile }\end{array}$ \\
\hline $\begin{array}{l}\text { Critical } \\
\text { facilities }\end{array}$ & $\begin{array}{l}\text { Assets crucial during an emergency (e.g. hospitals, police, and fuel } \\
\text { stations). }\end{array}$ & Google Earth images and OpenStreetMap & $\begin{array}{l}\text { ESRI } \\
\text { shapefile }\end{array}$ \\
\hline
\end{tabular}

layer of individual building footprints was obtained from Giuseppe Vilardo at the INGV - Vesuvius observatory. Buildings and their estimated primary use were identified from OpenStreetMap (OSM 2017) and Google maps data (Google Maps 2017), and grouped according to their use. The data do not go into detail about how many different uses are represented in a single building; it was decided that only the primary building use other than residential be required.

The 2011 ISTAT census reports the number of buildings by age category: those built before 1919, 1945, 1980, 2005, and those built after 2005 (ISTAT 2016). The oldest two categories, buildings constructed before than 1919 and between 1919 and 1945, were combined into a single layer to give the percentage of buildings older than 1945. These older buildings were chosen, because buildings of a similar age were known to have been damaged during the last unrest in the 1980s (Barberi et al. 1984).

\section{Transportation networks}

Road and rail networks were obtained from OpenStreetMap (OSM 2017) and validated by Google maps (Google Maps 2017). The roads were divided into five classes: motorway, primary, secondary, tertiary and residential. The rail network within Campi Flegrei is comprised of three main lines: the regional Circumflegrea and Cumana lines and the national Trenitalia line.

\section{Electricity network}

High voltage overhead lines and their related substations were identified from Google Earth images (Google Earth 2017). Smaller power and telephone lines were not included because they could not be clearly identified from aerial imagery.

\section{Critical facilities}

Critical facilities, such as hospitals, schools and public offices, were obtained from visually analysing Google Earth images and OpenStreetMap data (Google Earth 2017; OSM 2017).

\section{Data limitations}

Owing to the size of the caldera, a ground survey of this data was not feasible. Therefore, the majority of the spatial data was obtained from official sources (ISTAT, INGV), private mapping agencies (Google Maps and Earth) and a contributor-based mapping platform (OpenStreetMap). While easily accessible, these data sources and approaches have limitations including information bias, incorrect or outdated building use, outdated road and transportation networks and spatial errors.

\section{Vulnerability analysis and impact evaluation}

ArcGIS was used to analyse the distribution of the five exposed asset types in relation to the same unrest hazard scenario centred upon Pozzuoli, Agnano, and Baia. For simplicity, and due to a lack of detailed vulnerability data for all assets, this study assumed that all exposed assets located within the unrest hazard zones (1-4) had the potential to be impacted. However, buildings and roads were further analysed using two different vulnerability models: the earthquake building damage model by Zuccaro (2004) and the road damage model used by Anbazhagan et al. (2012) and Blake et al. (2017). These were chosen due to their relative simplicity, they could be applied to the study's exposure data, and in the case of the model used by Zuccaro (2004) have been used in an Italian setting. The potential damage to buildings was estimated by combining a seismic intensity that decreased gradationally away from the centre (Fig. 6) with probability curves for building damage (Fig. 7). 

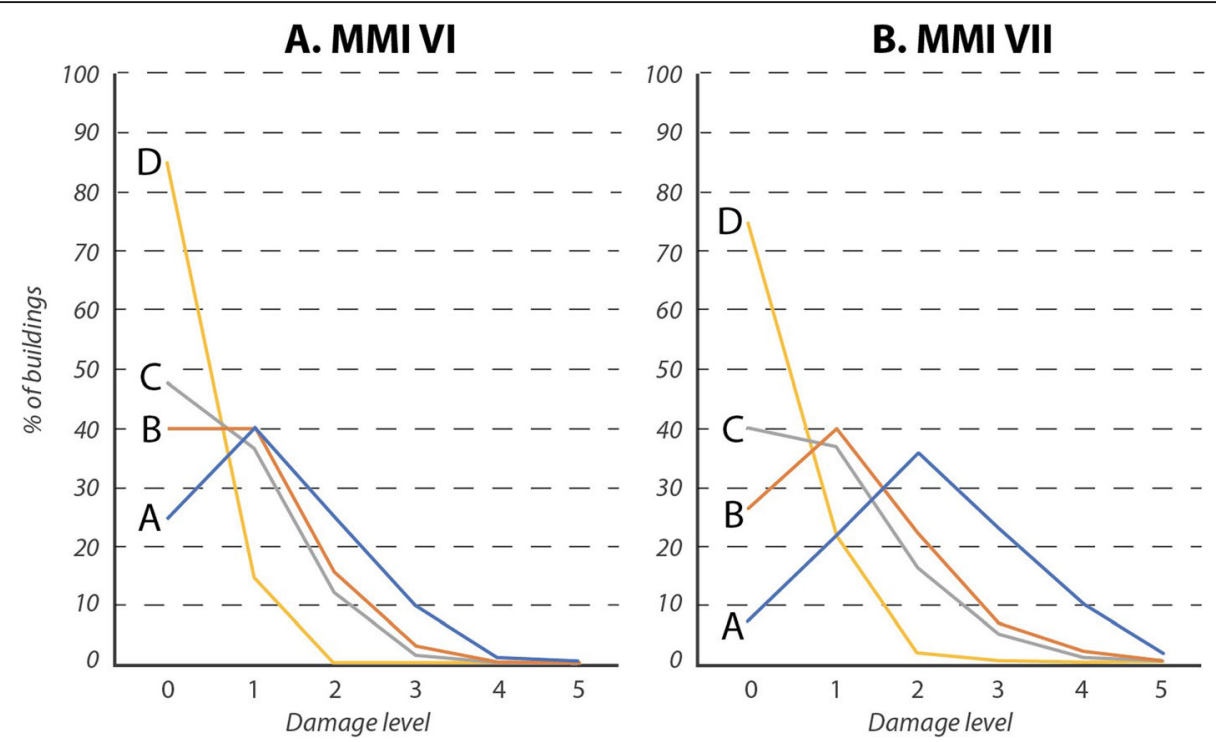

Fig. 7 Building damage probability curves based on work by Zuccaro (2004). These are divided based on the estimated seismic intensities: a) $\mathrm{MMI} \mathrm{VI}$ and $\mathbf{b}$ ) MMI VII. The lines represent different building vulnerabilities, these typologies range from the most vulnerable ' $A$ ' to the least 'D'. Criteria for vulnerability included construction material and rigidity of the structure. Damage probability curves calibrated for seismic events in Italy (Zuccaro 2004) were used, based on a scale of damage, zero equal to no damage, 5 representing total collapse (Zuccaro et al. 2008)

The damage probability curves followed the six-point scale used for seismic hazard in Italy, which ranges from 0 for "no damage" to 5 for "total collapse" (Fig. 7; Zuccaro 2004; Zuccaro et al. 2008). The damage caused by any given seismic intensity depends on construction type, height, age, and compliance with building codes (Faure Walker and Pousse 2017) and four main categories can be identified according to their rigidity (Zuccaro 2004; Zuccaro and Cacace 2010): Type A, unreinforced masonry structures with poor rigidity; Type $\mathrm{B}$, rubble masonry with medium rigidity; Type $\mathrm{C}$, strong masonry with high rigidity; and Type D, steel framed, high rigidity structures. Published data on the distribution of building types in Campi Flegrei are incomplete, so we used two approaches: either that all the buildings belonged to the most vulnerable category $\mathrm{A}$ or that they were distributed equally among all four categories A-D (Table 2).

The potential damage to roads was evaluated separately, applying the methods of Anbazhagan et al. (2012) and Blake et al. (2017) to assign four levels of relative damage that were assumed to decrease with increasing distance from the unrest scenario centre (severe, significant, moderate and light; Fig. 8). We allocate these categories assuming that they directly relate to Loss of Service (LoS) of that particular section of road. In these categories, severe and significant road damage will cause it to be impassable by motor transportation. Moderate and light damage will cause access difficulties, but not be impassable. No damage records from the previous unrest episodes at Campi Flegrei or any assessments of current road quality were available to increase our knowledge of potential road impacts, therefore it was deemed necessary to take this basic approach and make these assumptions. Processing was required on both the building and road GIS files in order for these assessments to be carried out. This involved detecting and correcting inaccurate or irrelevant data within the GIS and clipping the data to the selected locations.

\section{Results}

By overlaying the unrest hazard scenario on the distributions of population, buildings and other assets (Tables 3, 4 and 5) at three locations, we were able to carry out first-order impact assessments. Key results of the impact assessments are summarised in Figs. 9, 11 and 13. Figures 10, 12 and 14 show the spatial distributions of physical assets in the unrest hazard and evacuation zones for each of the scenario locations. These maps provide a general spatial overview of the exposed assets in each scenario location.

\section{Pozzuoli: hypothetical unrest hazard scenario and associated impacts}

The area affected by the Pozzuoli unrest hazard scenario lies primarily within the Pozzuoli commune and covers the town and main urban area in the region. A small portion extends into the neighbouring Naples 
Table 2 Building damage estimates used in this study based on work by Zuccaro (2004) and Zuccaro et al. (2008). Type A is the most vulnerable building type and $D$ is the least vulnerable building type. The damage levels are: zero $=$ no damage, $1=$ light damage, 2 = moderate damage, $3=$ major damage, $4=$ partial collapse and $5=$ total collapse

\begin{tabular}{|c|c|c|c|c|c|c|c|}
\hline \multirow{2}{*}{$\begin{array}{l}\text { Impact } \\
\text { zones }\end{array}$} & \multirow{2}{*}{$\begin{array}{l}\text { Distance } \\
\text { from } \\
\text { centre } \\
(\mathrm{km})\end{array}$} & \multirow[t]{2}{*}{$\mathrm{MMl}$} & \multirow{2}{*}{$\begin{array}{l}\text { Damage } \\
\text { level }\end{array}$} & \multicolumn{4}{|c|}{$\%$ damage for different building types } \\
\hline & & & & $\begin{array}{l}\text { A } \\
\text { Type }\end{array}$ & $\begin{array}{l}\text { B } \\
\text { Type }\end{array}$ & $\begin{array}{l}\text { C } \\
\text { Type }\end{array}$ & $\begin{array}{l}\text { D } \\
\text { Type }\end{array}$ \\
\hline \multirow[t]{6}{*}{ Zones $3 \& 4$} & \multirow[t]{6}{*}{$1-2 \mathrm{~km}$} & \multirow[t]{6}{*}{$\mathrm{Vl}$} & 0 & 23 & 40 & 48 & 85 \\
\hline & & & 1 & 40 & 40 & 37 & 15 \\
\hline & & & 2 & 25 & 16 & 12 & 0 \\
\hline & & & 3 & 10 & 4 & 3 & 0 \\
\hline & & & 4 & 2 & 0 & 0 & 0 \\
\hline & & & 5 & 0 & 0 & 0 & 0 \\
\hline \multirow[t]{6}{*}{ Zones 1 \& 2} & \multirow[t]{6}{*}{$<1 \mathrm{~km}$} & \multirow[t]{6}{*}{ VII } & 0 & 7 & 27 & 40 & 74 \\
\hline & & & 1 & 22 & 40 & 37 & 22 \\
\hline & & & 2 & 36 & 23 & 17 & 3 \\
\hline & & & 3 & 23 & 7 & 5 & 1 \\
\hline & & & 4 & 10 & 3 & 1 & 0 \\
\hline & & & 5 & 2 & 0 & 0 & 0 \\
\hline
\end{tabular}

\section{Hypothetical road damage zones}

\section{Primary}

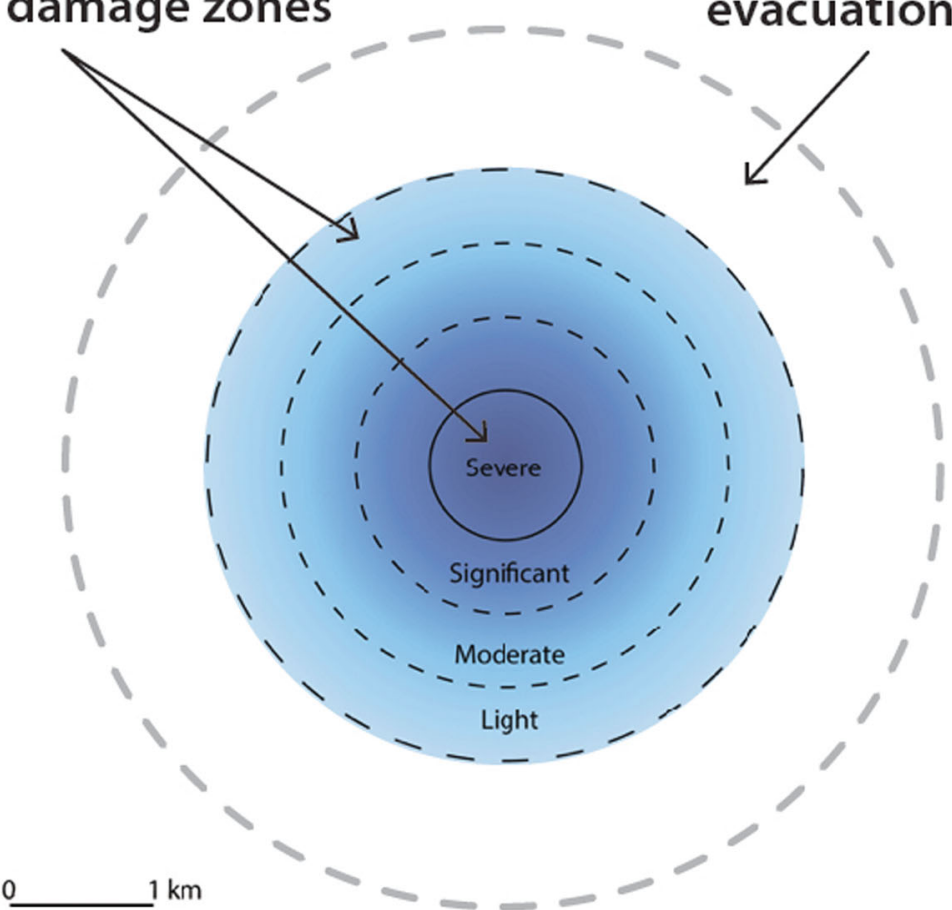

Fig. 8 Road damage scale used in this study modified from Anbazhagan et al. (2012) and Blake et al. (2017). The level of damage would affect the entire length of road within each zone 
Table 3 Counts of exposed assets for scenario 1 - Pozzuoli

\begin{tabular}{|c|c|c|c|c|c|c|c|}
\hline Exposure data & Scenario 1 - Pozzuoli & $\begin{array}{l}\text { Zone } 1(< \\
500 \mathrm{~m})\end{array}$ & $\begin{array}{l}\text { Zone } 2(500 \mathrm{~m}- \\
1 \mathrm{~km})\end{array}$ & $\begin{array}{l}\text { Zone } 3(1-1.5 \\
\mathrm{km})\end{array}$ & $\begin{array}{l}\text { Zone } 4 \text { (1.5-2 } \\
\mathrm{km})\end{array}$ & $\begin{array}{l}\text { unrest area (total) } \\
(<2 \mathrm{~km})\end{array}$ & PEZ (3 km) \\
\hline \multirow[t]{7}{*}{ Roads (m) } & Motorway & 0.0 & 0.0 & 0.0 & 1.8 & 1.8 & 12.7 \\
\hline & Primary & 0.0 & 0.0 & 2.4 & 1.1 & 3.5 & 7.1 \\
\hline & Secondary & 0.0 & 0.8 & 1.5 & 1.1 & 3.4 & 7.5 \\
\hline & Tertiary & 1.2 & 2.7 & 1.6 & 1.7 & 7.2 & 11.9 \\
\hline & Residential & 3.2 & 7.9 & 8.1 & 8.0 & 27.2 & 40.4 \\
\hline & Other & 4.8 & 12.3 & 8.3 & 11.6 & 36.9 & 92.0 \\
\hline & Total & 9.2 & 23.6 & 21.9 & 25.2 & 80.0 & 171.6 \\
\hline \multirow[t]{2}{*}{ Bus } & Stations & 0.0 & 0.0 & 1.0 & 0.0 & 1.0 & 1.0 \\
\hline & stops & 1.0 & 12.0 & 23.0 & 13.0 & 49.0 & 83.0 \\
\hline Ferry & Ports & 0.0 & 1.0 & 0.0 & 0.0 & 1.0 & 1.0 \\
\hline \multirow[t]{3}{*}{ Rail } & Lines & Cumana & $\begin{array}{l}\text { Cumana;NA- } \\
\text { RM; Other }\end{array}$ & $\begin{array}{l}\text { Cumana; NA- } \\
\text { RM;Other }\end{array}$ & $\begin{array}{l}\text { Cumana; NA- } \\
\text { RM;Other }\end{array}$ & $\begin{array}{l}\text { Cumana; NA-RM; } \\
\text { other }\end{array}$ & $\begin{array}{l}\text { Cumana NA- } \\
\text { RM Other }\end{array}$ \\
\hline & Total track & 0.6 & 4.1 & 4.7 & 4.6 & 14.0 & 21.7 \\
\hline & Stations & 1.0 & 3.0 & 0.0 & 1.0 & 5.0 & 6.0 \\
\hline \multirow{2}{*}{$\begin{array}{l}\text { Census (population) } \\
\text { approx. }\end{array}$} & Total (p1) & 3002.0 & 6745.0 & 6257.0 & 3421.0 & $19,425.0$ & $31,705.0$ \\
\hline & $\begin{array}{l}\text { Average density ( } \mathrm{p} 1 / \\
\text { area } \mathrm{km}^{2} \text { ) }\end{array}$ & $15,010.0$ & 9775.4 & 4776.3 & 1606.1 & 7792.0 & 2850.1 \\
\hline \multirow[t]{3}{*}{ Buildings } & Total & 142.0 & 526.0 & 590.0 & 508.0 & 1766.0 & 3580.0 \\
\hline & Residential & 110.0 & 416.0 & 513.0 & 443.0 & 1473.0 & 2991.0 \\
\hline & businesses & 32.0 & 96.0 & 57.0 & 47.0 & 232.0 & 529.0 \\
\hline \multirow[t]{10}{*}{ Main buildings use } & $\begin{array}{l}\text { Leisure and tourism } \\
\text { D2 }\end{array}$ & 1.0 & 5.0 & 7.0 & 8.0 & 21.0 & 29.0 \\
\hline & Hotels C1 & 3.0 & 5.0 & 3.0 & 5.0 & 16.0 & 28.0 \\
\hline & Shops A1 & 18.0 & 33.0 & 13.0 & 4.0 & 68.0 & 82.0 \\
\hline & Financial A2 & 2.0 & 2.0 & 3.0 & 1.0 & 8.0 & 8.0 \\
\hline & $\begin{array}{l}\text { restaurants \& cafes } \\
\text { A3 }\end{array}$ & 8.0 & 46.0 & 10.0 & 8.0 & 72.0 & 94.0 \\
\hline & offices B1 & 0.0 & 5.0 & 9.0 & 6.0 & 20.0 & 50.0 \\
\hline & General Industrial B2 & 0.0 & 0.0 & 12.0 & 15.0 & 27.0 & 199.0 \\
\hline & Distribution B8 & 0.0 & 0.0 & 0.0 & 0.0 & 0.0 & 15.0 \\
\hline & Public buildings D1 & 7.0 & 4.0 & 5.0 & 4.0 & 20.0 & 24.0 \\
\hline & Key Business zones & 1.0 & 1.0 & 2.0 & 1.0 & 2.0 & 3.0 \\
\hline \multirow[t]{3}{*}{ Electricity lines } & lines & 0.0 & 0.0 & 0.0 & 0.0 & 0.0 & 13.5 \\
\hline & pylons & 0.0 & 0.0 & 0.0 & 0.0 & 0.0 & 53.0 \\
\hline & substations & 0.0 & 0.0 & 0.0 & 0.0 & 0.0 & 1.0 \\
\hline \multirow[t]{5}{*}{ Critical facilities } & Medical D3 & 0.0 & 0.0 & 0.0 & 0.0 & 0.0 & 0.0 \\
\hline & Police and fire & 0.0 & 0.0 & 0.0 & 0.0 & 0.0 & 2.0 \\
\hline & Petrol & 0.0 & 0.0 & 2.0 & 2.0 & 4.0 & 6.0 \\
\hline & Military & 0.0 & 0.0 & 1.0 & 0.0 & 1.0 & 1.0 \\
\hline & Schools D4 & 3.0 & 7.0 & 4.0 & 4.0 & 18.0 & 21.0 \\
\hline$\%$ on land & Area $\left(\mathrm{km}^{2}\right)$ & 0.2 & 0.8 & 1.4 & 2.1 & 4.5 & 11.1 \\
\hline Commune & Name & Pozzuoli & Pozzuoli & Pozzuoli & Pozzuoli & Pozzuoli & $\begin{array}{l}\text { Pozzuoli and } \\
\text { Naples }\end{array}$ \\
\hline
\end{tabular}


Table 4 Counts of exposed assets for scenario 2 - Agnano

\begin{tabular}{|c|c|c|c|c|c|c|c|}
\hline Exposure data & Scenario 2 - Agnano & $\begin{array}{l}\text { Zone } 1(< \\
500 \mathrm{~m})\end{array}$ & $\begin{array}{l}\text { Zone } 2(500 \mathrm{~m}- \\
1 \mathrm{~km})\end{array}$ & $\begin{array}{l}\text { Zone } 3(1- \\
1.5 \mathrm{~km})\end{array}$ & $\begin{array}{l}\text { Zone } 4 \text { (1.5-2 } \\
\text { km) }\end{array}$ & $\begin{array}{l}\text { unrest area (total) } \\
(<2 \mathrm{~km})\end{array}$ & PEZ (3 km) \\
\hline \multirow[t]{7}{*}{ Roads (m) } & Motorway & 4.6 & 3.4 & 3.3 & 5.1 & 16.4 & 23.5 \\
\hline & Primary & 0.0 & 0.0 & 0.4 & 1.6 & 2.0 & 7.3 \\
\hline & Secondary & 0.9 & 1.4 & 1.1 & 7.8 & 11.2 & 24.3 \\
\hline & Tertiary & 0.9 & 2.3 & 2.0 & 2.7 & 7.9 & 23.4 \\
\hline & Residential & 0.4 & 2.3 & 6.2 & 13.0 & 21.9 & 85.8 \\
\hline & Other & 10.8 & 25.9 & 41.6 & 62.3 & 140.7 & 210.1 \\
\hline & Total & 17.6 & 35.3 & 54.6 & 92.5 & 200.0 & 374.4 \\
\hline \multirow[t]{2}{*}{ Bus } & Stations & 0.0 & 0.0 & 0.0 & 0.0 & 0.0 & 2.0 \\
\hline & stops & 4.0 & 10.0 & 12.0 & 41.0 & 67.0 & 193.0 \\
\hline Ferry & Ports & 0.0 & 0.0 & 0.0 & 0.0 & 0.0 & 0.0 \\
\hline \multirow[t]{3}{*}{ Rail } & track & 0.0 & 0.0 & 0.0 & Circumflegrea & 1.6 & $\begin{array}{l}\text { Circumflegrea } \\
\text { Cumana }\end{array}$ \\
\hline & total track & 0.0 & 0.0 & 0.0 & 1.6 & 1.6 & 40.2 \\
\hline & stations & 0.0 & 0.0 & 0.0 & 1.0 & 1.0 & 9.0 \\
\hline \multirow{2}{*}{$\begin{array}{l}\text { Census (population) } \\
\text { approx. }\end{array}$} & Total (p1) & 1229.0 & 1527.0 & 6950.0 & $16,351.0$ & 26,057 & $136,912.0$ \\
\hline & $\begin{array}{l}\text { Average density ( } \mathrm{p} 1 / \\
\text { area } \mathrm{km}^{2} \text { ) }\end{array}$ & 1380.9 & 829.9 & 1221.4 & 3330.1 & 1690.6 & 4614.5 \\
\hline \multirow[t]{3}{*}{ Buildings } & Total & 330.0 & 433.0 & 911.0 & 1321.0 & 2995.0 & 6539.0 \\
\hline & Residential & 258.0 & 309.0 & 744.0 & 1084.0 & 2395.0 & 5397.0 \\
\hline & businesses & 72.0 & 116.0 & 162.0 & 197.0 & 547.0 & 971.0 \\
\hline \multirow[t]{10}{*}{ Main Buildings use } & $\begin{array}{l}\text { Leisure and tourism } \\
\text { D2 }\end{array}$ & 5.0 & 5.0 & 15.0 & 17.0 & 42.0 & 124.0 \\
\hline & Hotels C1 & 0.0 & 1.0 & 3.0 & 10.0 & 14.0 & 28.0 \\
\hline & Shops A1 & 1.0 & 1.0 & 6.0 & 20.0 & 28.0 & 146.0 \\
\hline & Financial A2 & 0.0 & 0.0 & 0.0 & 0.0 & 0.0 & 8.0 \\
\hline & restaurants \& cafes A3 & 5.0 & 1.0 & 2.0 & 8.0 & 16.0 & 64.0 \\
\hline & offices B1 & 2.0 & 0.0 & 20.0 & 33.0 & 55.0 & 94.0 \\
\hline & General Industrial B2 & 59.0 & 108.0 & 113.0 & 86.0 & 366.0 & 475.0 \\
\hline & Distribution B8 & 0.0 & 0.0 & 3.0 & 23.0 & 26.0 & 32.0 \\
\hline & Public buildings D1 & 0.0 & 1.0 & 2.0 & 7.0 & 10.0 & 34.0 \\
\hline & Key Business zones & 1.0 & 2.0 & 3.0 & 3.0 & 9.0 & 5.0 \\
\hline \multirow[t]{3}{*}{ Electricity lines } & lines & 4.8 & 4.6 & 4.4 & 3.5 & 17.2 & 23.9 \\
\hline & pylons & 18.0 & 16.0 & 16.0 & 15.0 & 65.0 & 82.0 \\
\hline & substations & 1.0 & 1.0 & 0.0 & 0.0 & 1.0 & 1.0 \\
\hline \multirow[t]{5}{*}{ Critical Facilities } & Medical D3 & 0.0 & 0.0 & 0.0 & 1.0 & 1.0 & 1.0 \\
\hline & Police and fire & 0.0 & 0.0 & 0.0 & 1.0 & 1.0 & 2.0 \\
\hline & Petrol & 1.0 & 6.0 & 1.0 & 17.0 & 25.0 & 19.0 \\
\hline & Military & 0.0 & 0.0 & 0.0 & 0.0 & 0.0 & 14.0 \\
\hline & Schools D4 & 0.0 & 0.0 & 2.0 & 17.0 & 19.0 & 75.0 \\
\hline$\%$ on land & Area $\left(\mathrm{km}^{2}\right)$ & 0.8 & 2.4 & 3.9 & 5.5 & 12.5 & 27.2 \\
\hline Commune & Name & Naples & $\begin{array}{l}\text { Naples and } \\
\text { Pozz }\end{array}$ & $\begin{array}{l}\text { Naples and } \\
\text { Pozz }\end{array}$ & $\begin{array}{l}\text { Naples and } \\
\text { Pozz }\end{array}$ & Naples and Pozz & Naples and Pozz \\
\hline
\end{tabular}


Table 5 Counts of exposed assets for scenario 3 - Baia

\begin{tabular}{|c|c|c|c|c|c|c|c|}
\hline Exposure data & Scenario 3 - Baia & $\begin{array}{l}\text { Zone } 1(< \\
500 \mathrm{~m})\end{array}$ & $\begin{array}{l}\text { Zone } 2(500 \\
\mathrm{m}-1 \mathrm{~km})\end{array}$ & $\begin{array}{l}\text { Zone } 3(1- \\
1.5 \mathrm{~km})\end{array}$ & $\begin{array}{l}\text { Zone } 4(1.5- \\
2 \mathrm{~km})\end{array}$ & $\begin{array}{l}\text { Unrest area (total) } \\
(<2 \mathrm{~km})\end{array}$ & PEZ (3 km) \\
\hline \multirow[t]{7}{*}{ Roads (m) } & Motorway & 0.0 & 0.0 & 0.0 & 0.0 & 0.0 & 2.0 \\
\hline & Primary & 0.0 & 0.0 & 0.0 & 0.0 & 0.0 & 4.3 \\
\hline & Secondary & 1.0 & 2.0 & 1.2 & 1.4 & 5.6 & 9.0 \\
\hline & Tertiary & 0.6 & 3.6 & 5.0 & 6.0 & 15.2 & 35.6 \\
\hline & Residential & 0.2 & 4.0 & 10.4 & 9.9 & 24.6 & 58.8 \\
\hline & Other & 0.9 & 1.7 & 3.7 & 6.9 & 13.2 & 28.8 \\
\hline & Total & 2.7 & 11.3 & 20.3 & 24.2 & 58.5 & 138.5 \\
\hline \multirow[t]{2}{*}{ Bus } & Stations & 0.0 & 0.0 & 0.0 & 0.0 & 0.0 & 0.0 \\
\hline & stops & 1.0 & 13.0 & 9.0 & 10.0 & 33.0 & 104.0 \\
\hline Ferry/boat & Ports & 1.0 & 0.0 & 0.0 & 0.0 & 1.0 & 1.0 \\
\hline \multirow[t]{3}{*}{ Rail } & track & Cumana & Cumana & Cumana & Cumana & All Cumana & Cumana, CF, other \\
\hline & total track & 0.7 & 1.9 & 1.7 & 1.7 & 6.0 & 14.9 \\
\hline & stations & 0.0 & 0.0 & 2.0 & 0.0 & 2.0 & 5.0 \\
\hline \multirow{2}{*}{$\begin{array}{l}\text { Census } \\
\text { (population) } \\
\text { approx }\end{array}$} & Total (p1) & 427.0 & 2100.0 & 6233.0 & 7005.0 & $15,765.0$ & $42,637.0$ \\
\hline & $\begin{array}{l}\text { Average density ( } \mathrm{p} 1 / \\
\text { area } \mathrm{km}^{2} \text { ) }\end{array}$ & 1779.2 & 2121.2 & 3025.7 & 1704.4 & 2157.6 & 2299.7 \\
\hline \multirow[t]{3}{*}{ Buildings } & Total & 71.0 & 496.0 & 947.0 & 1068.0 & 2582.0 & 6229.0 \\
\hline & Residential & 40.0 & 408.0 & 843.0 & 949.0 & 2240.0 & 5455.0 \\
\hline & businesses & 30.0 & 79.0 & 94.0 & 110.0 & 313.0 & 707.0 \\
\hline \multirow[t]{10}{*}{ Main Buildings use } & $\begin{array}{l}\text { Leisure and tourism } \\
\text { D2 }\end{array}$ & 6.0 & 37.0 & 16.0 & 16.0 & 75.0 & 149.0 \\
\hline & Hotels C1 & 1.0 & 7.0 & 2.0 & 1.0 & 11.0 & 22.0 \\
\hline & Shops A1 & 2.0 & 6.0 & 31.0 & 9.0 & 48.0 & 169.0 \\
\hline & Financial A2 & 1.0 & 0.0 & 4.0 & 1.0 & 6.0 & 11.0 \\
\hline & $\begin{array}{l}\text { restaurants \& cafes } \\
\text { A3 }\end{array}$ & 9.0 & 12.0 & 15.0 & 13.0 & 49.0 & 99.0 \\
\hline & offices B1 & 0.0 & 4.0 & 11.0 & 14.0 & 29.0 & 76.0 \\
\hline & General Industrial B2 & 11.0 & 12.0 & 13.0 & 56.0 & 92.0 & 162.0 \\
\hline & Distribution B8 & 0.0 & 1.0 & 2.0 & 0.0 & 3.0 & 19.0 \\
\hline & Public buildings D1 & 1.0 & 2.0 & 6.0 & 1.0 & 10.0 & 24.0 \\
\hline & Key Business zones & 2.0 & 3.0 & 3.0 & 3.0 & 5.0 & 8.0 \\
\hline \multirow[t]{3}{*}{ Electricity lines } & lines & 0.0 & 0.5 & 3.8 & 2.4 & 6.8 & 10.2 \\
\hline & pylons & 0.0 & 1.0 & 14.0 & 12.0 & 27.0 & 39.0 \\
\hline & substations & 0.0 & 0.0 & 0.0 & 0.0 & 0.0 & 1.0 \\
\hline \multirow[t]{5}{*}{ Critical Facilities } & Medical D3 & 0.0 & 0.0 & 0.0 & 3.0 & 3.0 & 6.0 \\
\hline & Police and fire & 0.0 & 0.0 & 0.0 & 0.0 & 0.0 & 2.0 \\
\hline & Petrol & 0.0 & 2.0 & 2.0 & 3.0 & 7.0 & 12.0 \\
\hline & Military & 0.0 & 0.0 & 0.0 & 0.0 & 0.0 & 0.0 \\
\hline & Schools D4 & 0.0 & 5.0 & 0.0 & 1.0 & 6.0 & 16.0 \\
\hline$\%$ on land & Area $\left(\mathrm{km}^{2}\right)$ & 0.2 & 1.4 & 2.5 & 3.6 & 7.7 & 17.7 \\
\hline Commune & Name & Bacoli & $\begin{array}{l}\text { Naples and } \\
\text { Pozz }\end{array}$ & $\begin{array}{l}\text { Bacoli and } \\
\text { Pozz }\end{array}$ & $\begin{array}{l}\text { Bacoli and } \\
\text { Pozz }\end{array}$ & Bacoli and Pozz & $\begin{array}{l}\text { Bacoli, Pozz and Monte } \\
\text { di Procida }\end{array}$ \\
\hline
\end{tabular}




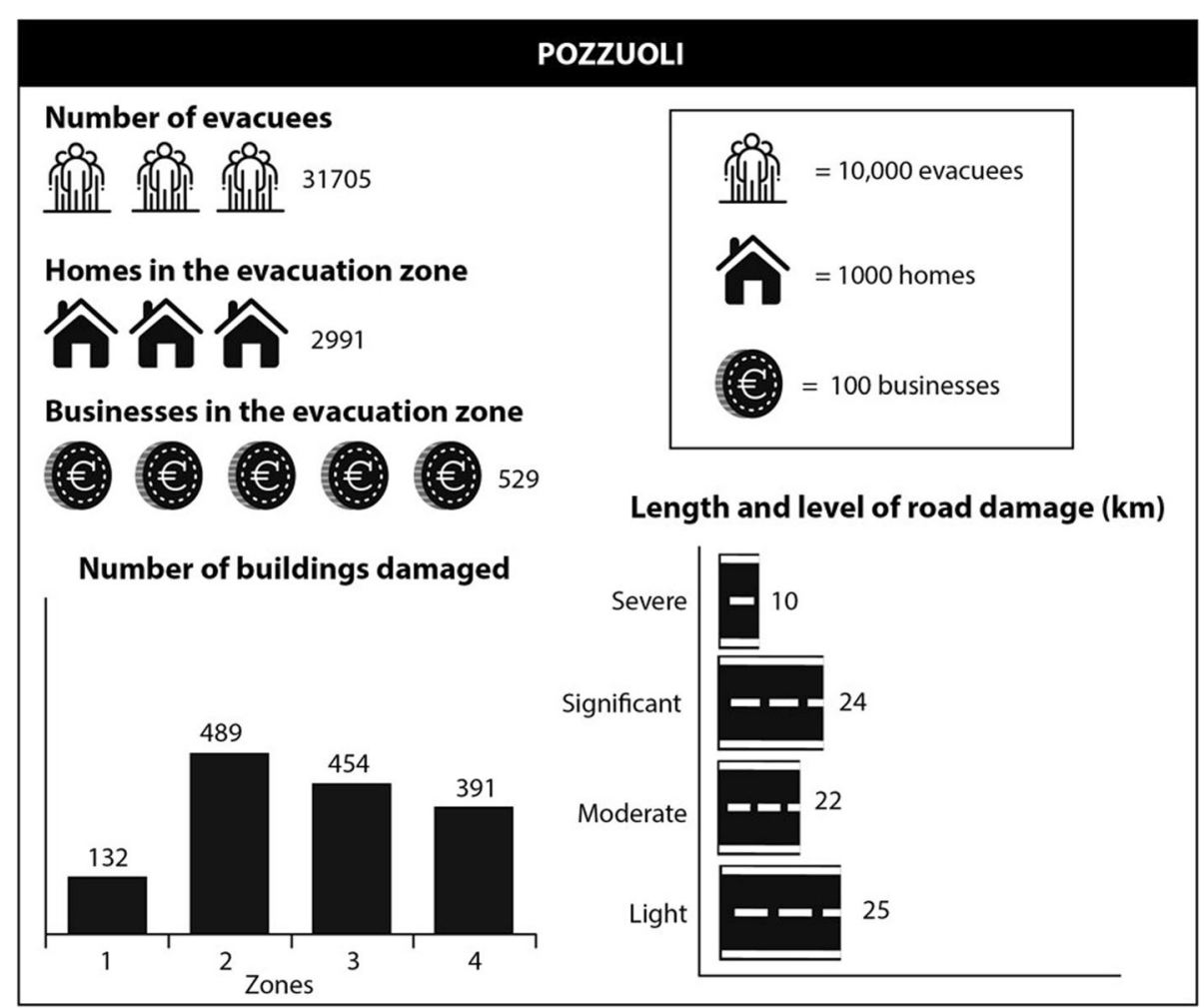

Fig. 9 Summary of the impacts of the Pozzuoli scenario. Building damage estimates are based on all the buildings classed as 'A' (most vulnerable)

commune. Pozzuoli's PEZ contains 2991 residential buildings, 31,705 potential evacuees and at least 529 individual businesses (Fig. 9; Table 3). The commercial heart of the town lies in the highest unrest hazard Zone 1. It consists of at least 142 buildings, of which $70 \%$ are high density residential; the remainder are retail units and restaurants (Table 3). The number of buildings expected to be partially or completely destroyed in this scenario ranges from 32 to 101, according to whether their types are equally distributed among Categories A-D or they all belong to Category A (Table 7). Ten kilometres of road (out of $171 \mathrm{~km}$ in the PEZ) would be severely damaged or blocked, and five railway stations along two commuter railway lines (the metropolitana and cumana lines) and the main port are at risk of being put out of use (Fig. 10). Light damage may occur to about 2 $\mathrm{km}$ of the A56 (or Tangenziale), which is the main motorway that runs east to west across Campi Flegrei. When all four unrest hazard zones are considered, 18 schools, 4 fuel stations, the Aeronautical Academy next to Solfatara, and the Roman archaeological sites of the Serapeo marketplace and beneath Rione Terra are vulnerable to damage in this scenario (Table 3; Fig. 10).

\section{Agnano: hypothetical hazard scenario and associated impacts}

The area covered by the Agnano scenario is split between the Pozzuoli and Naples communes and covers the areas of Bagnoli, Fuorigrotta and Agnano. The PEZ contains 6539 buildings, 136,912 potential evacuees and 971 individual businesses (Fig. 11; Table 4). Zone 1 lies within a large industrial region, as well as medium density housing. It contains 330 buildings, $78 \%$ are residential; the remainder are general industry such as manufacturing and warehousing (Table 4). The number of buildings expected to be partially or completely destroyed in this scenario ranges from 41 to 136, according to whether their types are equally distributed among Categories A-D or they all belong to Category A (Table 7). $52 \mathrm{~km}$ of road (out of $374 \mathrm{~km}$ in the PEZ) would be severely damaged or blocked, including $8.5 \mathrm{~km}$ of the Tangenziale (Fig. 11). Twenty four kilometres of electricity lines and 82 pylons, about $25 \%$ of Campi Flegrei's high voltage electricity network, lie within the PEZ (Table. 4). A large electricity substation is also located within the highest impact zone (Figs. 12 and 18). The Circumflegrea and Cumana railways lines also run through the hazard area, as well as connecting Naples with communities 


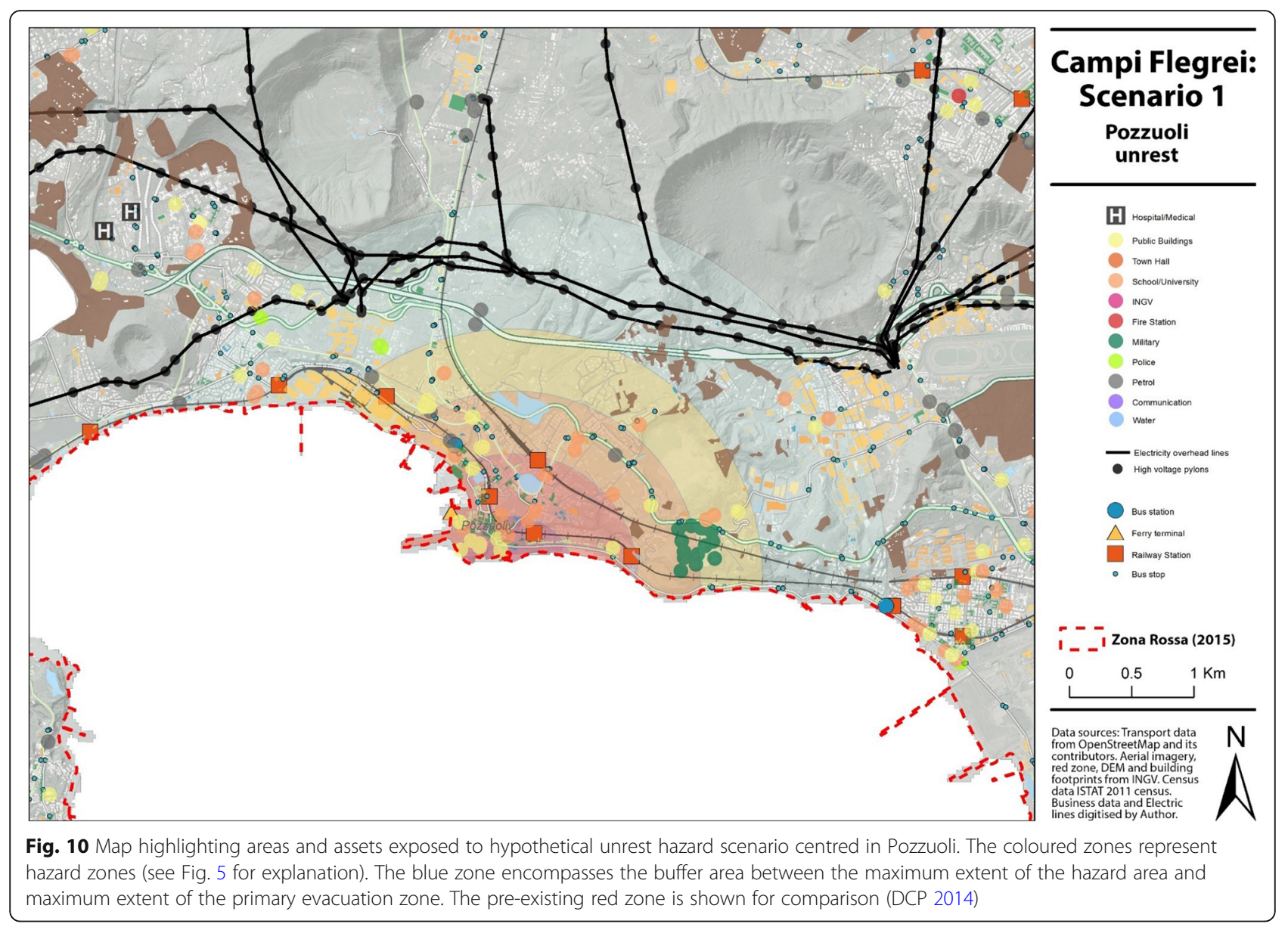

further West (Fig. 12). When all four unrest hazard zones are considered, at least 19 school buildings, 25 fuel stations and one hospital are vulnerable to damage in this scenario (Table 4; Fig. 12).

Baia: hypothetical hazard scenario and associated impacts The area covered by the Baia unrest hazard scenario covers the three communes of Monte di Procida, Bacoli and Pozzuoli. The Baia scenario PEZ contains 5455 residential buildings, 42,637 evacuees and 707 businesses (Fig. 13; Table 5). Of the 71 buildings in Zone 1 , the majority are for general industry and manufacturing along the coast (e.g. boat building and fisheries; Fig. 14). Two large archaeological sites at Castello di Baia and Terme di Baia, as well as the port could be damaged in Zone 1. The number of buildings expected to be partially or completely destroyed in this scenario ranges from 31 to 107, according to whether their types are equally distributed among Categories A-D or they all belong to Category A (Table 7). Fourteen kilometres of road (out of $138 \mathrm{~km}$ in the PEZ) would be severely damaged or blocked and the Cumana railway line interrupted (Fig. 14). Nearly eleven kilometres of electricity lines, 39 pylons and 1 substation are within the PEZ. When all four hazard zones are considered, 6 school buildings, 7 fuel stations and three hospital buildings are vulnerable to damage in this scenario (Table 5; Fig. 14).

\section{Summary}

More than 7300 buildings lie within the three unrest hazard scenarios, 1766 in Pozzuoli, 2582 in Baia and 2995 in Agnano (Fig. 15a). If they are all assumed to belong to the most vulnerable Category $\mathrm{A}$, the damage probability curves (Fig. 7) indicate that the number of buildings expected to suffer some degree of damage are 1459 in Pozzuoli, 2425 in Agnano and 2076 in Baia (Table 6; Fig. 16). If the building types are distributed equally among Categories A to D, the corresponding numbers become 975, 1615 and 1349 (Table 7; Fig. 16). Assuming all of the buildings belong to the most vulnerable Category A, the numbers expected to partially or totally collapse are 101 in Pozzuoli, 136 in Agnano and 107 in Baia; in comparison, assuming an equal distribution, the numbers are 32, 41 and 31 (Table. 7). 


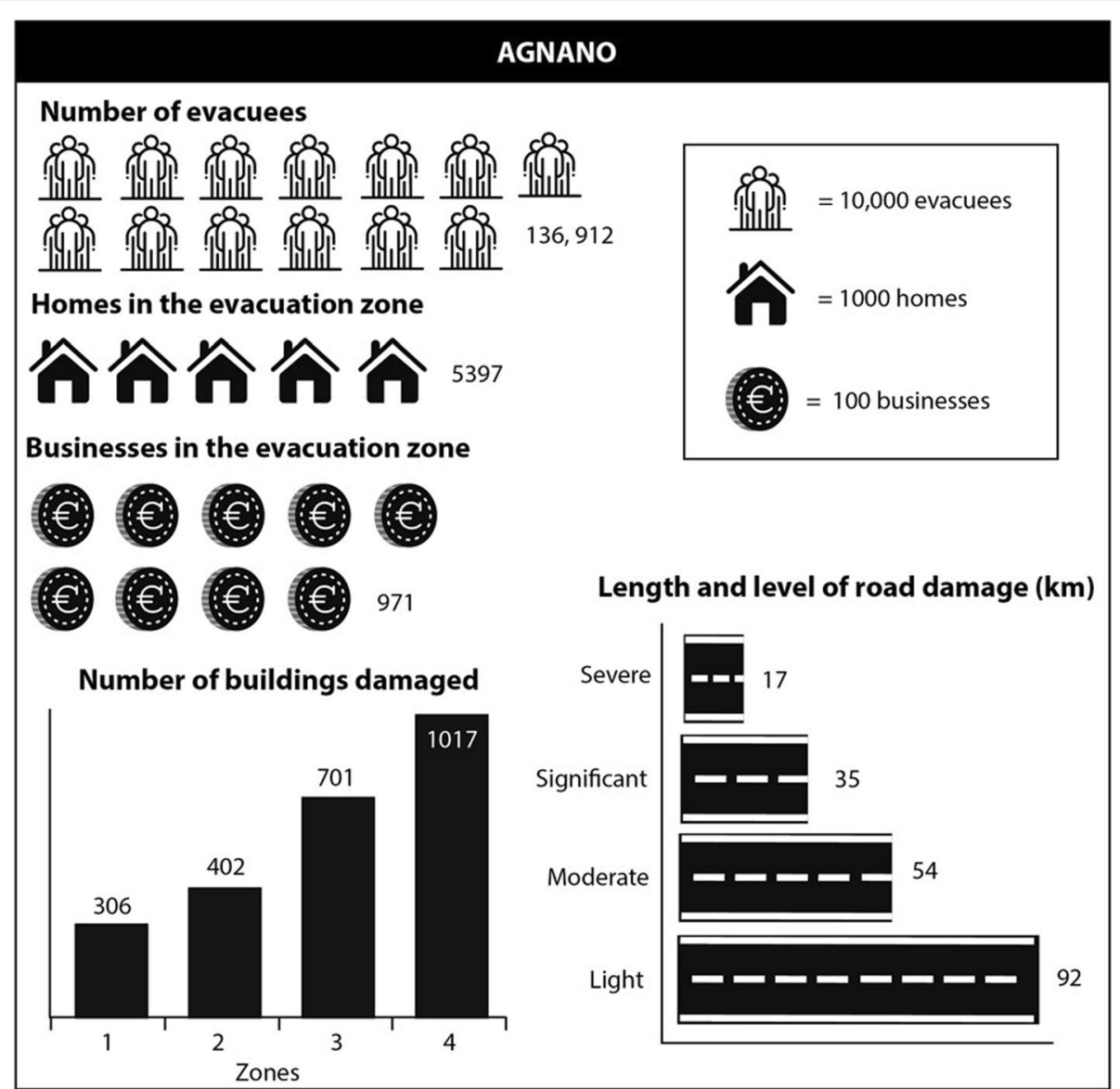

Fig. 11 Summary of the impacts of the Agnano scenario. Building damage estimates are based on all the buildings classed as ' $\mathrm{A}$ ' (most vulnerable)

The combined population within the hypothetical unrest hazard zones exceeds 19,425 in Pozzuoli, 26, 057 in Agnano and 15,765 in Baia (Tables 3, 4 and $5)$. However, the total number in the three evacuation zones (PEZs) is nearly 3.5 times greater, at more than 210,000 people or about three people in every five across the entire caldera: 31,705 in Pozzuoli, 136,912 in Agnano and 42,637 in Baia (Fig. 15b). The road networks are expected to be disrupted across all the unrest hazard zones (Table 6; Fig. 17). Roads with significant or severe damage may become unusable to ordinary vehicles and represent $41 \%, 26 \%$ and $24 \%$ of the roads in the hazard zones in Pozzuoli, Agnano and Baia, respectively (Tables 3, 4 and 5).

\section{Discussion}

The impact from unrest hazards associated with an awakening of Campi Flegrei have been assessed and presented. We considered and combined two caldera unrest hazards with a range of exposure datasets within a simple but effective impact assessment across three test locations. Key impacts are summarised in Table 8, together with our initial thoughts on possible cascading effects. The complex and interconnected nature of societal systems within the caldera make many sectors vulnerable to disruption from long term volcanic unrest. However, this table as well as the final results could serve as a starting point to initiate discussions with stakeholders regarding long term preparedness and short term crisis response in the region.

\section{Damage estimates}

The number of buildings damaged during unrest has a direct impact on the potential for evacuation and on the ability of businesses to continue in operation. Rubble from building damage will cause roads to become blocked and potential unusable. For example, roads after L'Aquila earthquake in 2009 were impassable due to building damage (Zuccaro and Cacace 2010). The number of buildings damaged is controlled by the density of buildings in each hazard zone as well as their physical vulnerability to seismicity and 


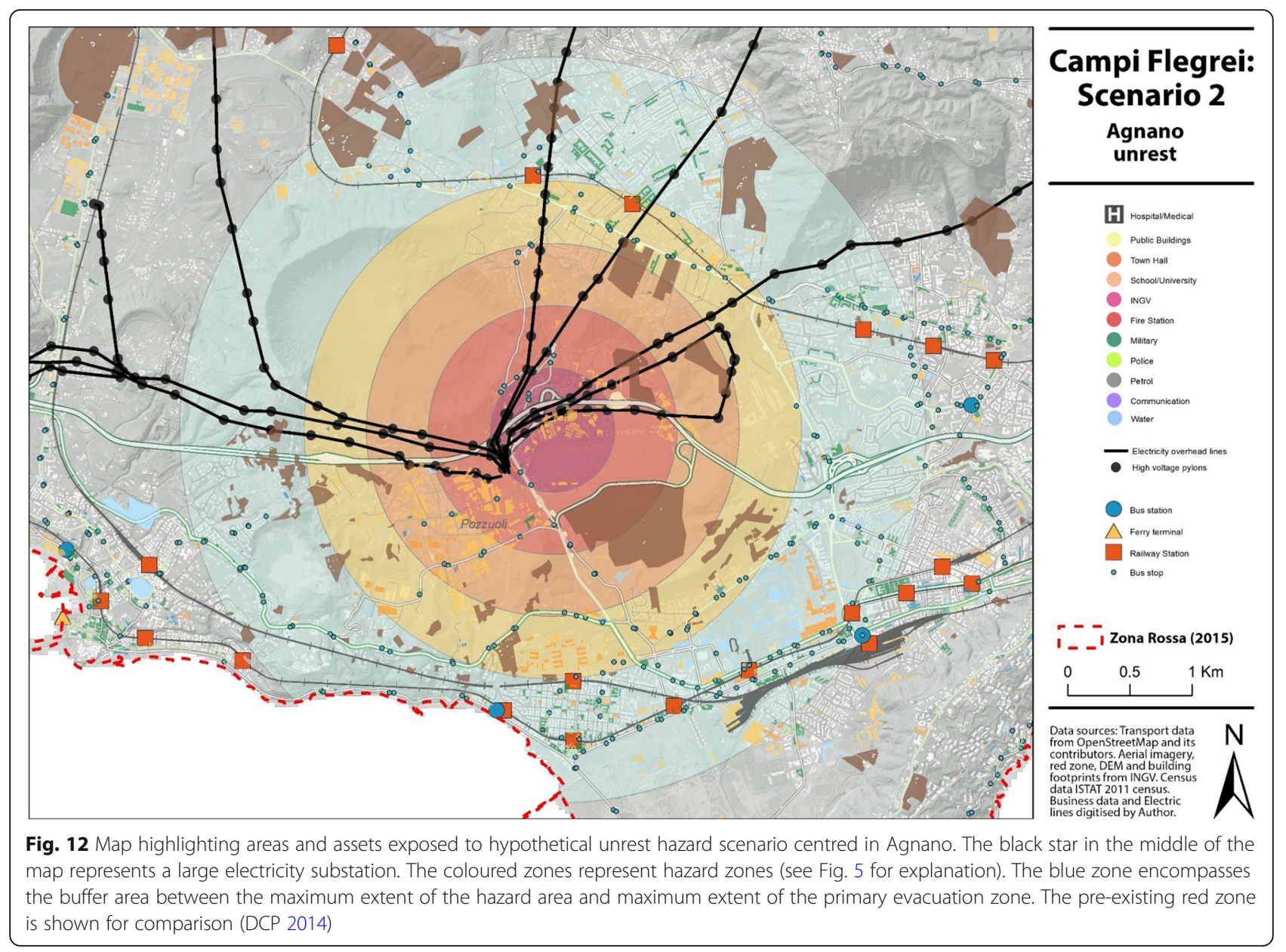

ground uplift. Individual impact assessments suggest damage can be expected to be between about 975 and 2400 buildings, with partial or total collapse of between 31 and 136 (Table 7). Most buildings expected to partially or totally collapse lie in the inner unrest hazard Zone 1, which may experience shaking intensities up to MMI VII (Table 7). More specifically, the numbers of buildings partially or totally destroyed from the Pozzuoli scenario (between 32 and 101 depending on the vulnerability classification: Table 7) lie within the range of 70 buildings partially or totally estimated to be damaged as a result of the 1982-84 unrest (Barberi et al. 1984; Branno et al. 1984). Zuccaro and Cacace (2010) did not provide estimates on the number of buildings potentially damaged in their scenario for comparison. However, both studies agree that the dense road network across the region will be vulnerable to the potential blockages from rubble and debris from damaged structures positioned along the road network. Throughout the caldera, retail and service industries would also suffer loss of service and drops in income, because of reduced accessibility to supplies and customers. Reduced access would be magnified by blockage of the Tangenziale, which is the only three-lane road connection across Campi Flegrei and a crucial evacuation route. Damage to approximately $8.5 \mathrm{~km}$ of this motorway is expected for unrest beneath Agnano and $1 \mathrm{~km}$ for unrest centred on Pozzuoli. Such damage would severely restrict evacuation by forcing traffic onto minor roads causing traffic bottlenecks. Future volcanic unrest would disrupt communities and businesses outside the immediate area, especially districts such as Monte di Procida around the western tip of Campi Flegrei, that rely on vehicular access being secured throughout the rest of the caldera.

\section{Evacuation estimates}

Results show that local evacuations during unrest may involve the displacement of 31,000-136,000 residents, depending on the locus of unrest (Fig. 15a). Furthermore, the dense road network and rapid urbanisation 


\section{BAIA}

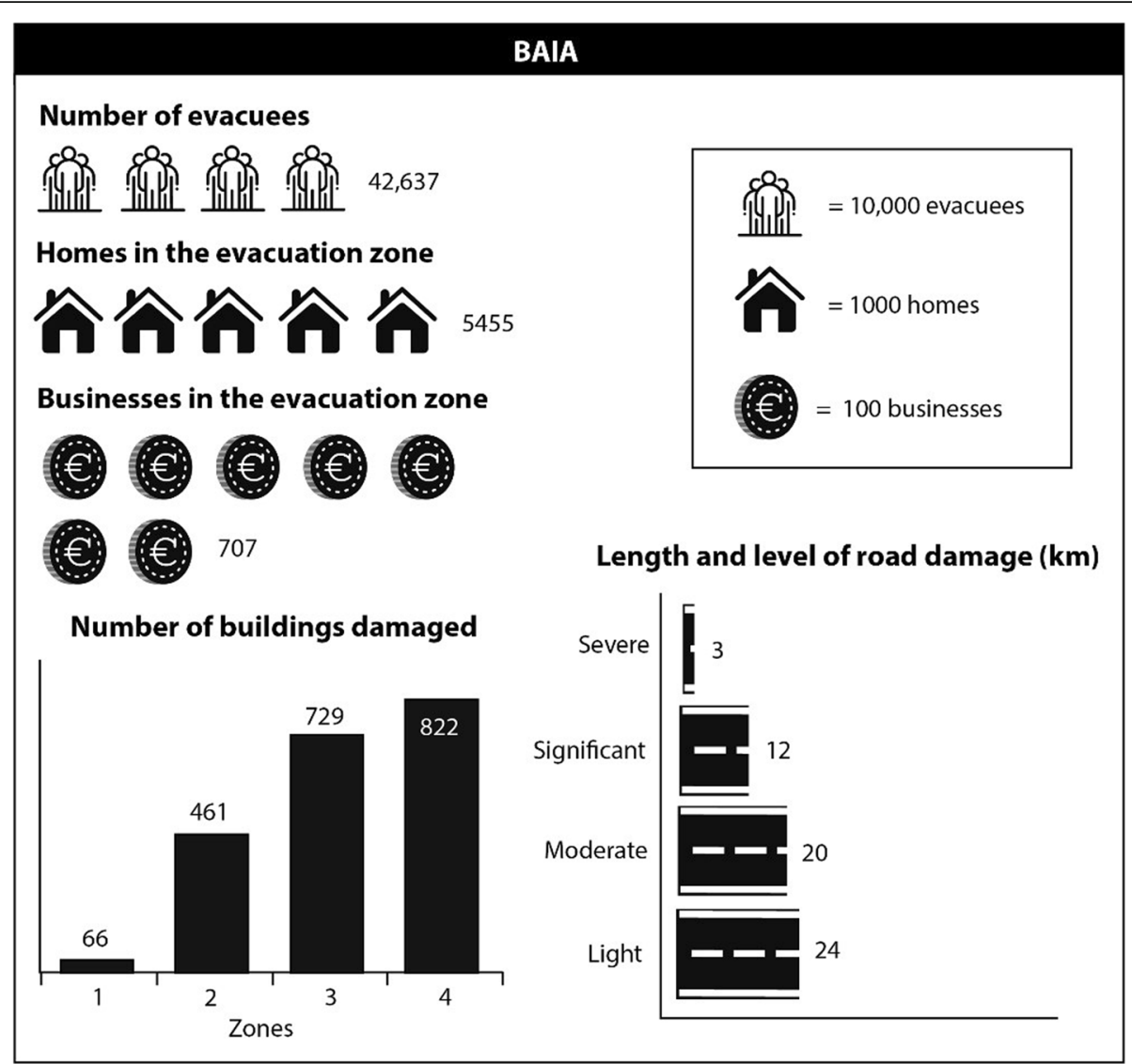

Fig. 13 Summary of the impacts of the Baia scenario. Building damage estimates are based on all the buildings classed as 'A' (most vulnerable)

in Campi Flegrei means that road based evacuation from the three test locations could be challenging (Fig. 17). By focusing on smaller evacuation areas in Campi Flegrei, we have been able to look at individual assets, potential impacts and the interaction between systems. This work supplements the only other published study on evacuation at Campi Flegrei by Alberico et al. (2012). While Alberico et al. (2012) used a larger PEZ (known as the Emergency Planning Zone in their study) focusing on regional evacuation, our results are in agreement that communities in the South West region (Monte di Procida) could find it difficult to evacuate the region by road. As experienced in 1982-84, harbours and the ability to use ferries for evacuation could be affected by ground uplift (Alberico et al. 2012), exacerbating the difficulties for communities in coastal regions.

\section{Disruption to electricity supplies}

Campi Flegrei's electricity network is especially dense across its northern sector (Fig. 18) and is particularly exposed in the Agnano scenario, where $17 \mathrm{~km}$ of electricity lines are in the hazard zone. In all scenario locations, however, damage to pylons or substations from ground uplift and seismicity would leave communities, businesses and transportation networks without power. The consequences would accumulate, should simultaneous disruption to the road network restrict access to repair the facilities and hamper response efforts. Virtually every other sector depends on electricity to function, while the power sector rely on functional roads for access to sites damaged or in need of maintenance.

\section{Impacts on businesses}

Between $12-18 \%$ of the buildings in all three scenario locations are for non-residential purposes. However, the proportions of these devoted to specific types of activity vary considerably (Fig. 19). Thus, the proportion used for general industry ranges from $71 \%$ for Agnano, to 32\% for Baia and 10\% for Pozzuoli. In contrast, Pozzuoli has the largest proportion of retail 


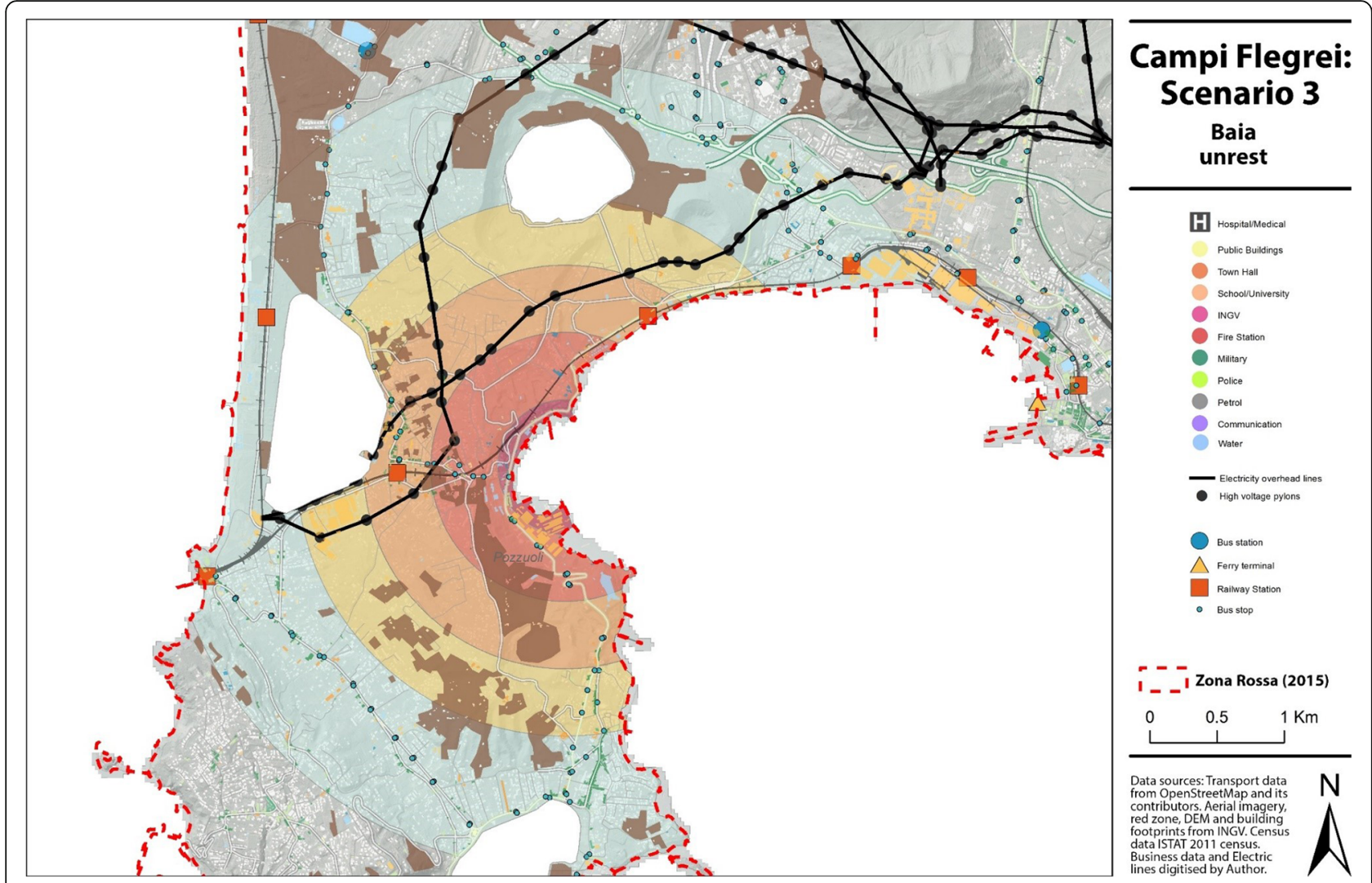

Fig. 14 Map highlighting areas and assets exposed to hypothetical unrest hazard scenario centred in Baia. The coloured zones represent hazard zones (see Fig. 5 for explanation). The blue zone encompasses the buffer area between the maximum extent of the hazard area and maximum extent of the primary evacuation zone. The pre-existing red zone is shown for comparison (DCP 2014)

and restaurants (52\%; compared with $27 \%$ in Baia and 9\% in Agnano), whereas Baia has the largest amount of businesses in the leisure and tourism sector $(23 \%$; compared with $10 \%$ in Pozzuoli and $7 \%$ in Agnano).

We suggest that three factors will threaten all three categories of business during future unrest: (1) direct damage to premises; (2) business interruption caused by disrupted transport routes; and (3) loss of earnings due to evacuation and negative media coverage. Tourism is expected to be disproportionately affected, as demonstrated during unrest in Long Valley, California (Blong 1984) and at Taupō caldera New Zealand (Johnston et al. 2002). A collapse in tourism will be especially damaging to Pozzuoli and Baia (Fig. 19) because of their dependence on leisure activities, hotels, retail, and restaurants and cafes. Pozzuoli is also a principal port for tourism to the neighbouring islands of Procida, Ischia and Capri. Ground movement interrupted the port's activities in 1982-1984 (Barberi et al. 1984) and is expected to do so during similar unrest in the future. Hence, even the islands will suffer economic losses due to renewed unrest at Pozzuoli and potentially elsewhere in the caldera.

\section{Limitations and future work}

As with any scenario approach, the examples presented here are only a guide to what might happen during future unrest. It is not possible to test the accuracy of this scenario until the next unrest occurs. These impact assessments would be enhanced if up to date information on household demographics and building vulnerability were used (e.g., the type of structure, nature of the construction, and details of expected ground-motion at a particular site), and if the cascading consequences of unrest (e.g., the knock-on costs of business interruption and evacuation) were quantified. Refinements will also be possible if it could be identified whether most building damage during previous unrest was caused by ground uplift, persistent, low-level volcano-tectonic seismicity (with magnitudes less than 2), or 

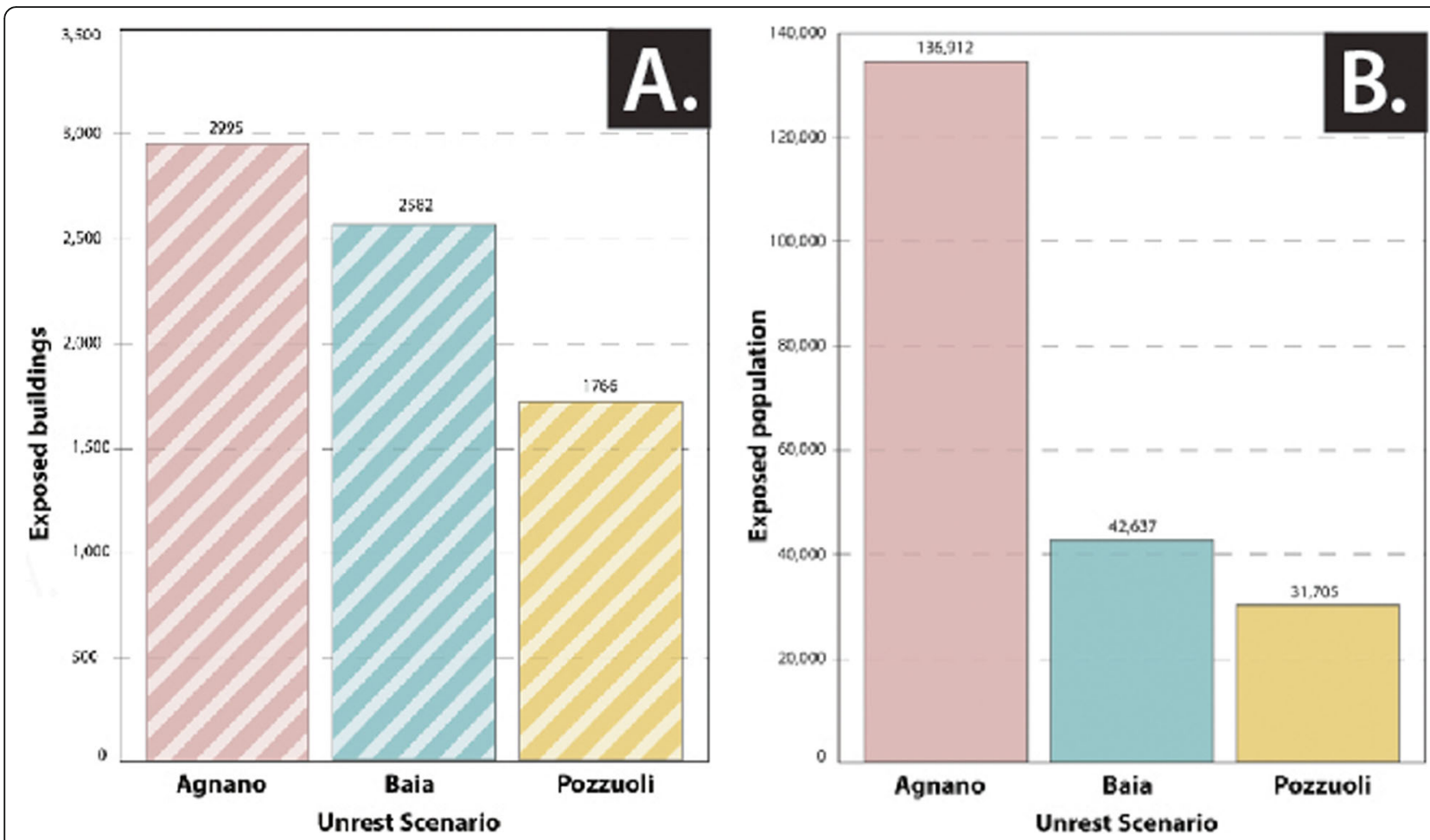

Fig. 15 Population and buildings exposed to the hazard in each location: (a) Buildings within unrest hazard scenario locations; and (b) Population within evacuation zones (PEZ)

individual, larger earthquakes (up to 4.0 in 1982-84). Such distinction is particularly important because future unrest may involve a greater number of volcano-tectonic earthquakes per metre of uplift than previously recorded (Kilburn et al. 2017).

Maps showing impact have the advantage of providing different users with practical information for their specific interests. They identify the impact on well-defined targets (such as local populations, buildings and power supplies), and can encourage interaction between groups tasked with dealing with different aspects of an emergency. These maps (or variations thereof) should not be used for public engagement until the data they contain have been verified by local communities and lifeline managers. Therefore, future development of the maps and approach should be led and co-developed by relevant stakeholders (e.g. local and national civil defence, infrastructure and facilities managers) within Campi Flegrei. More specifically, further work could evaluate physical and systemic vulnerabilities with electricity managers within the region and ideally be driven by the community (e.g. Davies and Davies 2018).

\section{Conclusions}

The 1969-1972 and 1982-1984 emergencies at Campi Flegrei have shown how building damage during volcanic unrest can lead to mass evacuations. Three impact assessments have been used here to investigate the potential impact of future unrest on buildings and livelihoods across the caldera. Our newly developed unrest scenario has considered renewed ground uplift centred beneath the important population centres of

Table 6 Summary of main results from the impact assessment

\begin{tabular}{lllll}
\hline Scenario & $\begin{array}{l}\text { Number of buildings within unrest } \\
\text { zones }\end{array}$ & $\begin{array}{l}\text { Number } \\
\text { damaged }^{\mathrm{a}}\end{array}$ & $\begin{array}{l}\text { Length of road within unrest zones } \\
(\mathrm{km})\end{array}$ & $\begin{array}{l}\text { Significant - severe road damage } \\
(\mathrm{km})\end{array}$ \\
\hline Pozzuoli & 1766 & 1459 & 80 & 33 \\
Agnano & 2995 & 2425 & 200 & 52 \\
Baia & 2582 & 2076 & 59 & 14
\end{tabular}

${ }^{\mathrm{a}}$ Based on assuming $100 \%$ of buildings are of the most vulnerable building class and combining all damage classes from light to total damage 


\section{A. Pozzuoli}

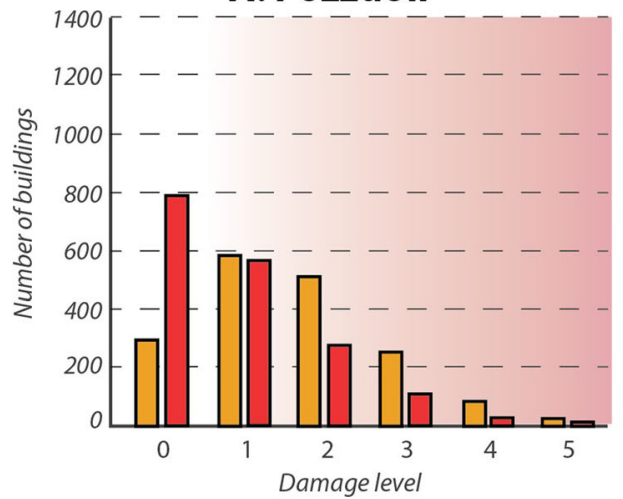

C. Baia

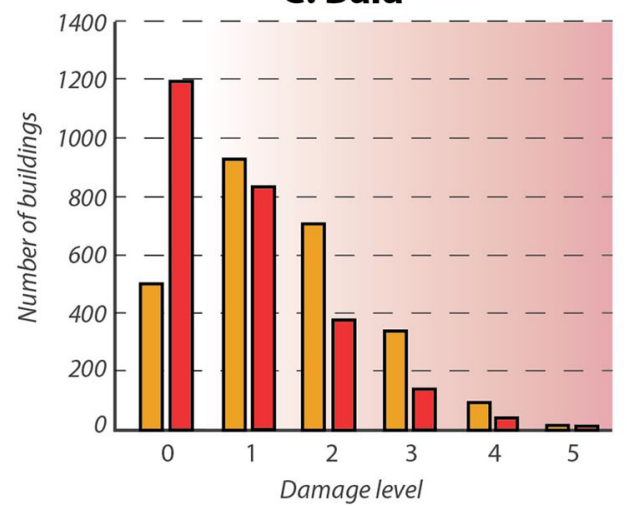

B. Agnano

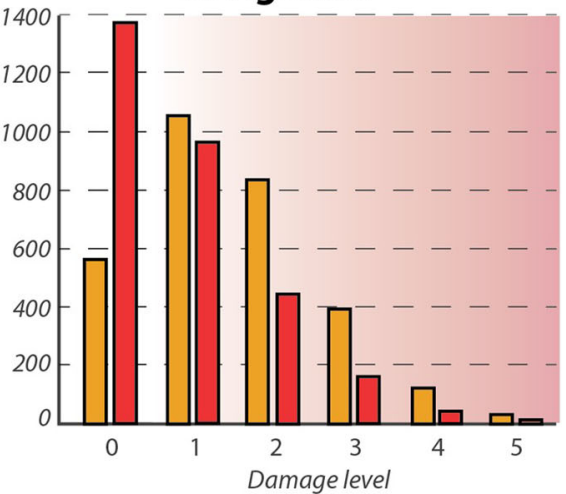

$100 \%=$ Vulnerability level $\mathrm{A}$

Equal quantities of all

vulnerability levels $(25 \%=A, B, C \& D)$

\section{Damage levels}

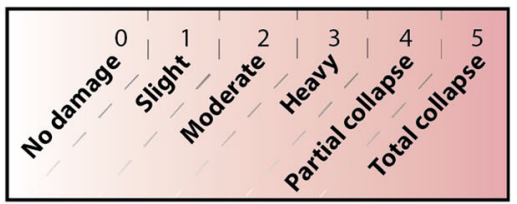

Fig. 16 Number of estimated building damages for each of the scenarios and how the numbers differ between assumptions: (a) Pozzuoli, (b) Agnano, and (c) Baia. percentage damage data from Table 2 was multiplied with number of buildings that fall within each scenario area

Table 7 Damage estimates from the impact assessment, showing two assumptions about the distribution of building types and corresponding levels of damage. $A$ is the most vulnerable building type and $D$ is the least vulnerable building type

\begin{tabular}{|c|c|c|c|c|c|c|c|c|}
\hline \multirow[t]{2}{*}{ Scenario } & \multirow[t]{2}{*}{ Assumption } & \multirow[t]{2}{*}{ MMl } & \multicolumn{6}{|c|}{ No of buildings and damage level } \\
\hline & & & No Damage & Light & Minor & Major & $\begin{array}{l}\text { Partial } \\
\text { Collapse }\end{array}$ & $\begin{array}{l}\text { Total } \\
\text { Collapse }\end{array}$ \\
\hline \multirow[t]{4}{*}{ Pozzuoli } & \multirow[t]{2}{*}{$100 \%=A$} & $\mathrm{Vl}$ & 258 & 439 & 274 & 109 & 22 & 0 \\
\hline & & VII & 46 & 146 & 240 & 153 & 66 & 13 \\
\hline & \multirow[t]{2}{*}{$25 \%=A, B, C, D$} & $\mathrm{VI}$ & 544 & 362 & 142 & 46 & 5 & 0 \\
\hline & & VII & 247 & 202 & 131 & 60 & 23 & 4 \\
\hline \multirow[t]{4}{*}{ Agnano } & \multirow[t]{2}{*}{$100 \%=A$} & $\mathrm{Vl}$ & 453 & 892 & 558 & 223 & 45 & 0 \\
\hline & & VII & 117 & 167 & 274 & 175 & 76 & 15 \\
\hline & \multirow[t]{2}{*}{$25 \%=A, B, C, D$} & $\mathrm{VI}$ & 1098 & 736 & 295 & 94 & 11 & 0 \\
\hline & & VII & 282 & 230 & 150 & 69 & 26 & 4 \\
\hline \multirow[t]{4}{*}{ Baia } & \multirow[t]{2}{*}{$100 \%=A$} & $\mathrm{Vl}$ & 396 & 806 & 503 & 201 & 40 & 0 \\
\hline & & VII & 46 & 125 & 204 & 130 & 56 & 11 \\
\hline & \multirow[t]{2}{*}{$25 \%=A, B, C, D$} & $\mathrm{VI}$ & 964 & 664 & 236 & 85 & 10 & 0 \\
\hline & & VII & 269 & 171 & 111 & 51 & 19 & 2 \\
\hline
\end{tabular}



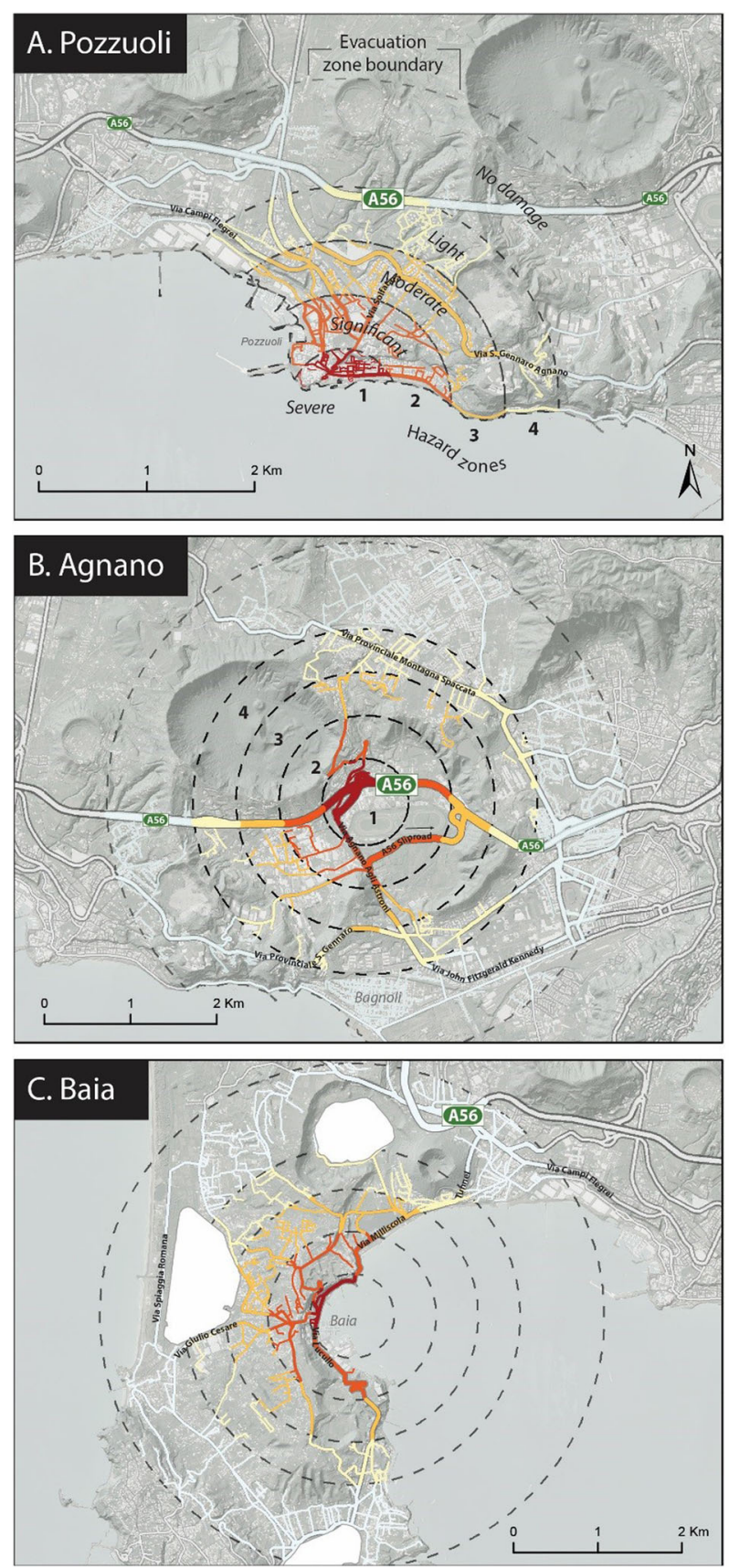

\section{Campi Flegrei Unrest Scenarios}
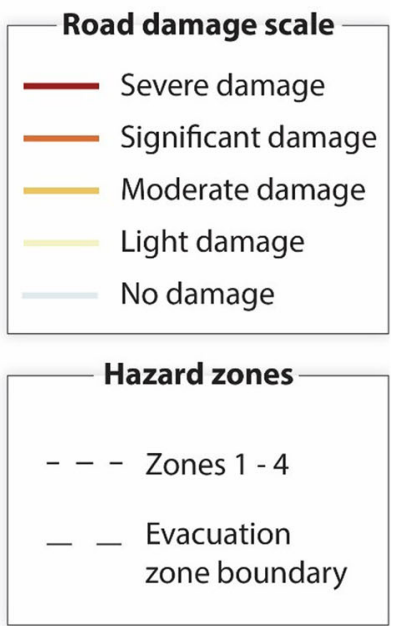

Fig. 17 Estimated scale of road damage within the (a) Pozzuoli; (b) Agnano; (c) Baia unrest hazard areas

Baia, Pozzuoli and Agnano in, respectively, western, central and eastern Campi Flegrei. The scenario applied to Pozzuoli assumes a continuation of the pattern of unrest observed since 1950. The examples located in Baia and Agnano take account of the possibility that the centre of uplift may move significantly before an eruption occurs.
The Agnano unrest scenario is associated with the greatest impact and involves the potential evacuation of 136,000 people and damage to about 2400 buildings. The impact is large, because the location of the scenario lies entirely on land and includes densely populated residential districts and industrial centres. Agnano also lies between Naples and the rest of Campi Flegrei, so that 
Table 8 Summary of the key impacts and associated cascading effects for a future unrest scenario at Campi Flegrei, assuming the hazards causing these impacts are volcanic seismicity and ground deformation. Impact zones are defined as areas exposed to unrest hazards in scenario and not the whole evacuation area

\begin{tabular}{|c|c|c|}
\hline Type of impact & Estimated level of impact & Cascading effects \\
\hline Building damage & 1766-2995 buildings within unrest impact zones & $\begin{array}{l}\text { - Homes unable to be occupied. } \\
\text { - Repair or demolition costs. } \\
\text { - Businesses unable to operate. } \\
\text { - Fall in property values. } \\
\text { - Increasing insurance premiums. }\end{array}$ \\
\hline $\begin{array}{l}\text { Road and rail network } \\
\text { damage }\end{array}$ & 59-200 km of Roads within unrest impact zones & $\begin{array}{l}\text { - Reduced access for repairing } \\
\text { infrastructure. } \\
\text { - Business and critical facility supply } \\
\text { disruption. } \\
\text { - Disruption to evacuation } \\
\text { procedures. } \\
\text { - Worker commute disruption. } \\
\text { - Reduction in access for tourists. }\end{array}$ \\
\hline $\begin{array}{l}\text { Damage to electricity } \\
\text { network }\end{array}$ & $\begin{array}{l}7-17 \mathrm{~km} \text { of high voltage electricity network within unrest } \\
\text { impact zones }\end{array}$ & $\begin{array}{l}\text { - Business and critical facility supply } \\
\text { disruption. } \\
\text { - Disruption to road signals and } \\
\text { transport. } \\
\text { - Telecommunication disruption. } \\
\text { - Residential supply disruption. }\end{array}$ \\
\hline Evacuations & $31,000-136,000$ residents within primary evacuation areas. & $\begin{array}{l}\text { - Psychological stress and illness } \\
\text { - Displaced population. } \\
\text { - Loss of business revenue in } \\
\text { evacuation areas. } \\
\text { - Reduction in tourism. }\end{array}$ \\
\hline
\end{tabular}

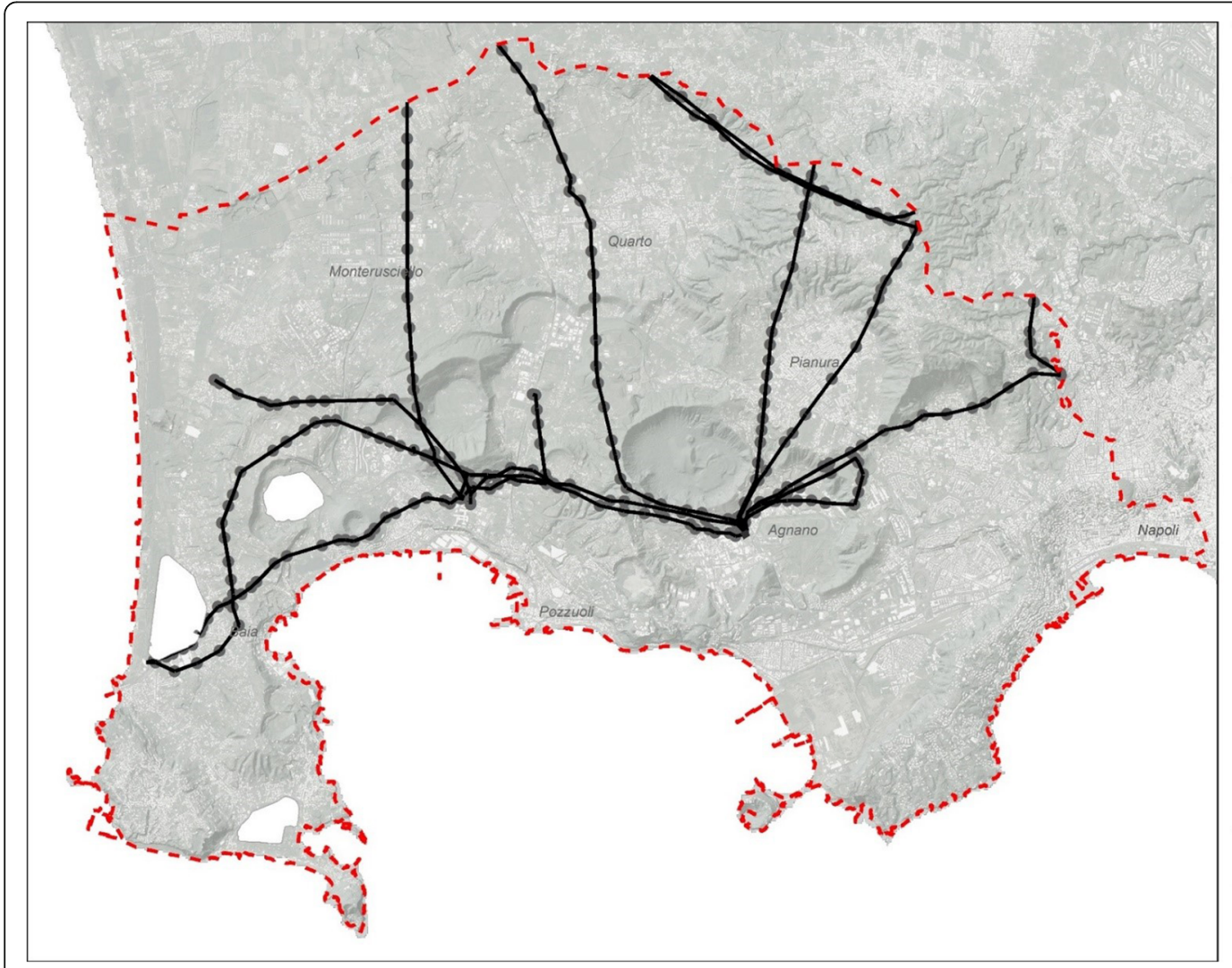

\section{Campi Flegrei: Electricity network}

Electric facilities

Disclaimer: This is not every
facility within the region

Electricity

overhead

lines

High voltage

- pylons

I Zona Rossa (2015)

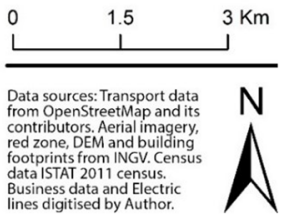

Fig. 18 High Voltage Electricity network digitised from Google Earth (2017) 

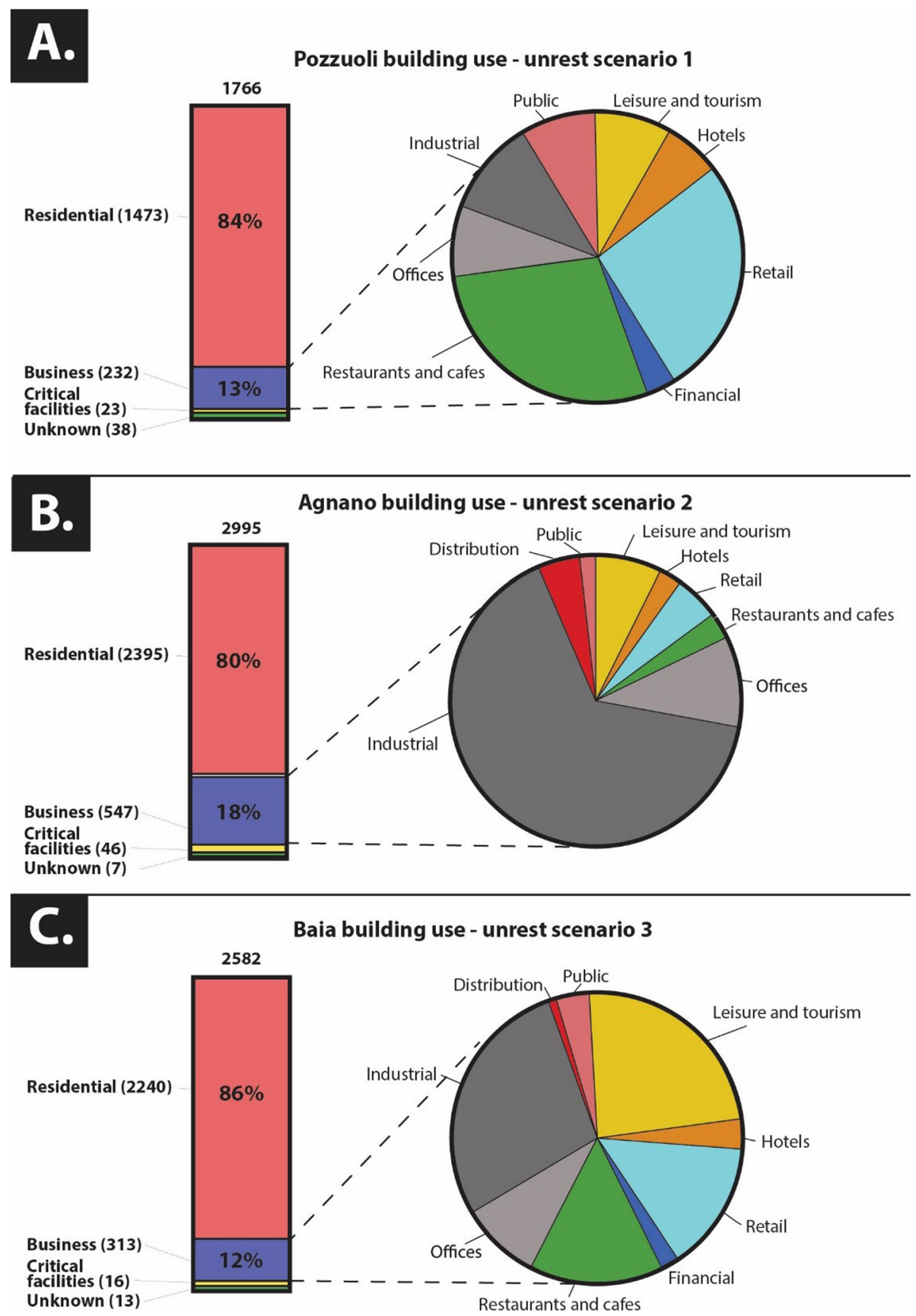

Fig. 19 Building use comparison across unrest hazard areas: (a) Pozzuoli; (b) Agnano; (c) Baia

damage to infrastructure, such as road networks and electricity lines, may trigger a cascade of obstacles to managing evacuations and repairs during an emergency. The results highlight the importance of considering examples in which renewed ground uplift is not necessarily focused again beneath Pozzuoli and how a simple scenario-based impact assessment can be used to explore and evaluate the impact of volcanic unrest across the whole caldera.
Abbreviations

DCP: National Department of Civil Protection.; INGV: Istituto Nazionale di Geofisica e Vulcanologia; ISTAT: The Italian National Institute of Statistics; LoS: Loss of Service; MMI: Modified Mercalli Intensity; PEZ: Primary Evacuation Zone; UTM: Universal Transverse Mercator

\section{Acknowledgements}

The authors would like to thank Giuseppe Vilardo for the GIS data and all those at the INGV in Naples for the many conversations about volcanic risk at Campi Flegrei which helped form the scope of this study. Also, thank you to both Natalia Deligne and Graham Leonard for discussions on the use of 
scenarios and to Eliza Calder and Anna Hicks for their comments. Finally, we are very grateful to the reviewers Tom Wilson and an anonymous reviewer for their time and for providing useful constructive feedback on the manuscript, and Jan Lindsay for editorial handling.

\section{Authors' contributions}

DC designed the project, carried out the GIS data collection, analysis and constructed the manuscript and figures. CK and SE provided guidance and input during the study, checked, and revised the manuscript. The author(s) read and approved the final manuscript.

\section{Funding}

This project was produced as partial fulfilment of Danielle Charlton's doctoral thesis, which was financially support by University College London's Impact Studentship and Aon Benfield Reinsurers (now Aon).

\section{Availability of data and materials}

The data are available in Tables 3-7.

\section{Competing interests}

The authors confirm there are no competing interests.

\section{Author details}

${ }^{1}$ School of Environment, University of Auckland, 23 Symonds Street, Auckland 1142, New Zealand. ' UCL Hazard Centre, Department of Earth Sciences, University College London, Gower Street, London WC1E 6BT, UK. ${ }^{3}$ INGV-Osservatorio Vesuviano, Via Diocleziano 328, 80124 Naples, Italy.

Received: 14 August 2019 Accepted: 10 July 2020

Published online: 25 July 2020

\section{References}

Acocella V, Di Lorenzo R, Newhall C, Scandone R (2015) An overview of recent (1988 to 2014) caldera unrest: knowledge and perspectives. Rev Geophys 53: 896-955

Alberico I, Lirer I, Petrosino P, Scandone R (2002) A methodology for the evaluation of long-term volcanic risk from pyroclastic flows in Campi Flegrei (Italy). J Volcanol Geotherm Res 116:63-78

Alberico I, Petrosino P, Lirer L (2011) Volcanic hazard and risk assessment in a multi-source volcanic area: the example of Napoli city (Southern Italy). Nat Hazards Earth Syst Sci 11:1057-1070

Alberico I, Petrosino P, Maglione G, Bruno L, Capaldo FS, Lirer I, Mazzola S (2012) Mapping the vulnerability for evacuation of the Campi Flegrei territorial system in case of a volcanic unrest. Nat Hazards 64:1823-1854

Anbazhagan P, Srinivas S, Chandran D (2012) Classification of road damage due to earthquakes. Nat Hazards 60(2):425-460

Avvisati G, Sessa EB, Colucci O, Marfè B, Marotta E, Nave R, Peluso R, Ricci T, Tomasone M (2019) Perception of risk for natural hazards in Campania region (southern Italy). Int J Disaster Risk Reduction 40:101164

Barberi F, Cassano E, La T, Sbrana P, A. (1991) Structural evolution of Campi Flegrei caldera in light of volcanological and geophysical data. J Geophys Res 48:33-49. https://doi.org/10.1016/0377-0273(91)90031-T

Barberi F, Corrado G, Innocenti F, Luongo G (1984) Phlegraean fields 1982-1984: brief chronicle of a volcano emergency in a densely populated area. Bull Volcanol 47:175-185

Bellucci F, Woo JYL, Kilburn CRJ, Rolandi G (2006) Ground deformation at Campi Flegrei, Italy: implications for hazard assessment. In: Troise, C., De Natale, G. and Kilburn, C. R. J. (eds.) Mechanisms of activity and unrest at large calderas. Geol Soc Lond, Spec Publ 269(1), 141-157

Benson C (2006) Volcanoes and the economy. In: Marti J, Ernst GGJ (eds) Volcanoes and the environment. Cambridge University Press, Cambridge, pp 440-467

Berrino G, Corrado G, Luongo G, Toro B (1984) Ground deformation and gravity changes accompanying the 1982 Pozzuoli uplift. Bull Volcanol 47:187-200

Bevilacqua A, Fourmentraux C, Bertagnini A, Bisson M, Esposti Ongaro T, Flandoli F, Isaia R, Neri A, Rosi M (2012) Mapping long term pyroclastic density current hazard in a caldera setting: application to Campi Flegrei caldera (Italy). In: EGU general assembly conference abstracts, vol 14, p 6688

Bevilacqua A, Isaia R, Neri A, Vitale S, Aspinall WP, Bisson M, Flandoli F, Baxter PJ, Bertagnini A, Esposti Ongaro T, lannuzzi E, Pistolesi M, Rosi M (2015) Quantifying volcanic hazard at Campi Flegrei caldera (Italy) with uncertainty assessment: I. Vent opening maps. J Geophys Res Solid Earth 120(4):23092329

Bevilacqua A, Neri A, Bisson M, Esposti Ongaro T, Flandoli F, Isaia R, Rosi M, Vitale $S$ (2017) The effects of vent location, event scale, and time forecasts on pyroclastic density current hazard maps at Campi Flegrei caldera (Italy). Front Earth Sci 5:72

Bianchi R, Coradini A, Federico C, Giberti G, Lanciano P, Pozzi J, Sartoris G, Scandone $R$ (1987) Modeling of surface deformation in volcanic areas: the 1970-1972 and 1982-1984 crises of Campi Flegrei, Italy. J Geophys Res Solid Earth 92(B13):14139-14150

Blake DM, Deligne NI, Wilson TM, Lindsay JM, Woods R (2017) Investigating the consequences of urban volcanism using a scenario approach II: insights into transportation network damage and functionality. J Volcanol Geotherm Res 340:92-116

Bland SH, Valoroso L, Stranges S, Strazzullo P, Farinaro E, Trevisan M (2005) Longterm follow-up of psychological distress following earthquake experiences among working Italian males: a cross-sectional analysis. J Nerv Ment Dis 193(6):420-423

Blong RJ (1984) Volcanic hazards: a sourcebook on the effects of eruption. Academic Press, Australia

Bodnar R, Cannatelli C, De Vivo B, Lima A, Belkin H, Milia A (2007) Quantitative model for magma degassing and ground deformation (bradyseism) at Campi Flegrei, Italy: implications for future eruptions. Geology. 35:791-794

Branno A, Esposito EGl, Luongo G, Marturano A, Porfido S, Rinaldis V (1984) The October 4th, 1983-magnitude 4 earthquake in Phlegraean fields: macroseismic survey. Bull Volcanol 47(2):233-238

Comune di Napoli (2019) Exe flegrei 2019. Available from: http://www.comune. napoli.it/flex/cm/pages/ServeBLOB.php/L/IT/IDPagina/39258 Accessed 2 Dec 2019

Corrado G, Guerra I, Lo Bascio A, Luongo G, Rampoldi R (1977) Inflation and microearthquake activity of Phlegraean fields, Italy. Bull Volcanol 40:169-188

Davies TR, Davies AJ (2018) Increasing communities' resilience to disasters: an impact-based approach. Int J Disaster Risk Reduction 31:742-749

Davis MS, Ricci T, Mitchell LM (2005) Perceptions of risk for volcanic hazards at Vesuvio and Etna, Italy. Aust J Disaster Trauma Stud 1:21

De Natale G, Zollo A, Del Gaudio C, Ricciardi GP, Martini M (1984) Error analysis in hypocentral locations at Phlegraean fields. Bull Volcanol 47(2):209-218

Del Gaudio C, Aquino I, Ricciardi GP, Ricco C, Scandone R (2010) Unrest episodes at Campi Flegrei: a reconstruction of vertical ground movements during 1905-2009. J Volcanol Geotherm Res 195:48-56

Deligne NI, Fitzgerald RH, Blake DM, Davies AJ, Hayes JL, Stewart C, Wilson G, Wilson TM, Castelino R, Kennedy BM, Muspratt S (2017) Investigating the consequences of urban volcanism using a scenario approach I: development and application of a hypothetical eruption in the Auckland volcanic field, New Zealand. J Volcanol Geotherm Res 336:192-208

Department of Civil Protection. (2014) Campania region bulletin. Available from: http://www.protezionecivile.gov.it/en/media-communication/dossier/detail/-/ asset_publisher/default/content/aggiornamento-del-piano-nazionale-diemergenza-per-i-campi-flegrei. Accessed: 14 Jan 2020

Di Vito MA, Acocella V, Aiello G, Barra D, Battaglia M, Carandente A, Del Gaudio C, de Vita S, Ricciardi GP, Ricco C, Scandone R (2016) Magma transfer at Campi Flegrei caldera (Italy) before the 1538 AD eruption. Sci Rep 6:32245

Faure Walker JP, Pousse G (2017) The perils: earthquake. In: Natural catastrophe risk management and modelling: a practitioner's guide. Wiley, Hoboken

Google Earth (2017). Available from: https://www.google.co.uk/intl/en_uk/earth/. Accessed 3 May 2017.

Google Maps (2017). Available from: https://www.google.co.uk/maps. Accessed 3 May 2017.

Hayes JL, Wilson TM, Deligne NI, Lindsay JM, Leonard GS, Tsang SW, Fitzgerald RH (2020) Developing a suite of multi-hazard volcanic eruption scenarios using an interdisciplinary approach. J Volcanol Geotherm Res 392:106763

Hughes JF, Healy K (2014) Measuring the resilience of transport infrastructure. N Z Transport Agency Res Rep 546:82

Instituto Nazionale di Geofisica e Vulcanologia - Osservatorio Vesuviano (INGV) (2016) Available from: http://www.ov.ingv.it/ov

ISTAT - National Institute for Statistics (2016) 15 censimento generale della poplazione, 2011. Dati sulle caratteristiche strutturale dellapopulazione e delle abitazioni, Rome. Available from: http://www.istat.it/en/

Johnston D, Scott BJ, Houghton B, Paton D, Dowrick DJ, Villamor P, Savage J (2002) Social and economic consequences of historic caldera unrest at the 
Taupo volcano, New Zealand and the management of future episodes of unrest. Bull N Z Soc Earthq Eng 35(4):215-230

Kaye G, Cole J, King A, Johnston D (2009) Comparison of risk from pyroclastic density current hazards to critical infrastructure in Mammoth Lakes, California, USA, from a new Inyo craters rhyolite dike eruption versus a dacitic dome eruption on Mammoth Mountain. Nat Hazards 49(3):541-563

Kilburn CR, De Natale G, Carlino S (2017) Progressive approach to eruption at Campi Flegrei caldera in southern Italy. Nat Commun 8:5312

Kuester I, Forsyth S (1985) Rabaul eruption risk: population awareness and preparedness survey. Disasters. 9:179-182

Lima A, De Vivo B, Spera FJ, Bodnar RJ, Milia A, Nunziata C, Belkin HE, Cannatelli C (2009) Thermodynamic model for uplift and deflation episodes (bradyseism) associated with magmatic-hydrothermal activity at the Campi Flegrei (Italy). Earth Sci Rev 97(1-4):44-58

Longo ML (2019) How memory can reduce the vulnerability to disasters: the bradyseism of Pozzuoli in southern Italy. AIMS Geosci 5(3):631-644

Lowenstein PL (1988) Rabaul Seismo-deformational crisis of 1983--85: monitoring, emergency planning and interaction with the authorities, the media and the public, report no. 88/32. Rabaul, Papua New Guinea, Rabaul Volcanological Observatory

Lyell C (1830-1833) Principles of geology. 3 vols. Murray, London

Mader GG, Blair ML, Olson RA (1987) Living with a volcanic threat: response to volcanic hazards, Long Valley, California, William Spangle, and Associates. Portola Valley, CA 105

Maj M, Starace F, Crepet P, Lobrace S, Veltro F, Marco F, Kemali D (1989) Prevalence of psychiatric disorders among subjects exposed to a natural disaster. Acta Psychiatr Scand 79(6):544-549

Mastrolorenzo G, Pappalardo L, Troise C, Rossano S, Panizza A, De Natale G (2006) Volcanic hazard assessment at the Campi Flegrei caldera. In: Troise, C., De Natale G, Kilburn CR J (eds.) Mechanisms of activity and unrest at large calderas. London

Mitchell-Wallace K, Jones M, Foote M, Hillier J (2017) Natural catastrophe risk management and modelling: a practitioner's guide. Wiley, Hoboken

Neri A, Bevilacqua A, Esposti Ongaro T, Isaia R, Aspinall WP, Bisson M, Flandoli F, Baxter PJ, Bertagnini A, lannuzzi E, Orsucci S, Pistolesi M, Rosi M, Vitale S (2015) Quantifying volcanic hazard at Campi Flegrei caldera (Italy) with uncertainty assessment: II. Pyroclastic density current invasion maps. J Geophys Res Solid Earth 120:JB011776

Newhall CG, Dzurisin D (1988) Historical unrest at large calderas of the world. U.S. G.P.O., Bulletin 1855, 2 v. 1108

OpenStreetMap (2017) Map data copyrighted OpenStreetMap contributors and available from: https://www.openstreetmap.org

Orsi G, Di Vito M, Isaia R (2004) Volcanic hazard assessment at the restless Campi Flegrei caldera. Bull Volcanol 66:514-530

Orsi G, Di Vito MA, Selva J, Marzocchi W (2009) Long-term forecast of eruption style and size at Campi Flegrei caldera (Italy). Earth Planet Sci Lett 287:265-276

Panza GF, Irikura K, Kouteva-Guentcheva M, Peresan A, Wang Z (2011) Advanced seismic hazard assessment: part II: regional seismic hazard and seismic microzonation case studies. Pure Appl Geophys 168(3-4)

Parascandola A (1947) I fenomeni bradisismici del Serapeo di Pozzuoli. Stabilmento tipografico G, Genovese

Paris R, Ulvrova M, Selva J, Brizuela B, Costa A, Grezio A, Lorito S, Tonini R (2019) Probabilistic hazard analysis for tsunamis generated by subaqueous volcanic explosions in the Campi Flegrei caldera, Italy. J Volcanol Geotherm Res 379: 106-116

Paton D, Johnston DM, Johal S (2013) Human impacts of hazards. In: Bobrowsky PT (ed) Encyclopedia of natural hazards. Encyclopedia of earth sciences series. Springer, Dordrecht

Phillipson G, Sobradelo R, Gottsmann J (2013) Global volcanic unrest in the 21st century: an analysis of the first decade. J Volcanol Geotherm Res 264:183196

Pingue F, Petrazzuoli SM, Obrizzo F, Tammaro U, De Martino P, Zuccaro G (2011) Monitoring system of buildings with high vulnerability in presence of slow ground deformations (the Campi Flegrei, Italy, case). Measurement 44(9): 1628-1644

Potter SH, Scott BJ, Jolly GE, Johnston DM, Neall VE (2015) A catalogue of caldera unrest at Taupo Volcanic Centre, New Zealand, using the volcanic unrest index (VUI). Bull Volcanol 77(9):78

Ricci T, Barberi F, Davis MF, Isaia R, Nave R (2013) Volcanic risk perception in the Campi Flegrei area. J Volcanol Geotherm Res 254:118-130
Selva J, Costa A, De Natale G, Di Vito MA, Isaia R, Macedonio G (2018) Sensitivity test and ensemble hazard assessment for tephra fallout at Campi Flegrei, Italy. J Volcanol Geotherm Res 351:1-28

Selva J, Costa A, Sandri L, Macedonio G, Marzocchi W (2014) Probabilistic shortterm volcanic hazard in phases of unrest: a case study for tephra fallout. J Geophys Res Solid Earth 119:B011252

Selva J, Orsi G, Di Vito M, Marzocchi W, Sandri L (2012) Probability hazard map for future vent opening at the Campi Flegrei caldera, Italy. Bull Volcanol 74: $497-510$

Smith VC, Isaia R, Pearce NJG (2011) Tephrostratigraphy and glass compositions of post-15 kyr Campi Flegrei eruptions: implications for eruption history and chronostratigraphic markers. Quat Sci Rev 30:3638-3660. https://doi.org/10. 1016/j.quascirev.2011.07.012

Strong K, Carpenter O, Ralph D (2020) Developing scenarios for the insurance industry. Cambridge centre for risk studies at the University of Cambridge Judge Business School and Lighthill Risk Network. Published online: https:// lighthillrisknetwork.org/wp-content/uploads/Insurance_DevelopingScenarios. pdf

Troiano A, Di Giuseppe MG, Petrillo Z, Troise C, De Natale G (2011) Ground deformation at calderas driven by fluid injection: modelling unrest episodes at Campi Flegrei. Geophys J Int 187:833-847

Troise C, De Natale G, Schiavone R, Somma R, Moretti R (2019) The Campi Flegrei caldera unrest: discriminating magma intrusions from hydrothermal effects and implications for possible evolution. Earth Sci Rev 188, 108-122

United States Geological Survey (2006) Shakemap Manual. Available from: https:// pubs.usgs.gov/tm/2005/12A01/pdf/508TM12-A1.pdf. Accessed 12 Dec 2017.

Woo JYL (2007) Ground deformation at Campi Flegrei, Southern Italy: an indicator for the magmatic feeding system. PhD Thesis. University College London

Zuccaro, G. (2004) Final report SAVE. Available from: http://gndt.ingvit/Att_scient/ Prodotti_attesi_2004/Dolce_Zuccaro/Mappe/Start2.html [accessed 12th June 2014]

Zuccaro G, Cacace F (2010) Seismic impact scenarios in the volcanic areas in Campania. In: Mazzolani F (ed) Urban habitat constructions under catastrophic events. London, UK, Taylor \& Francis Group

Zuccaro G, Cacace F, Spence RJS, Baxter PJ (2008) Impact of explosive eruption scenarios at Vesuvius. J Volcanol Geotherm Res 178(3):416-453

\section{Publisher's Note}

Springer Nature remains neutral with regard to jurisdictional claims in published maps and institutional affiliations.

Ready to submit your research? Choose BMC and benefit from:

- fast, convenient online submission

- thorough peer review by experienced researchers in your field

- rapid publication on acceptance

- support for research data, including large and complex data types

- gold Open Access which fosters wider collaboration and increased citations

- maximum visibility for your research: over $100 \mathrm{M}$ website views per year

At BMC, research is always in progress.

Learn more biomedcentral.com/submissions 